\title{
Nanoparticles for Bone Tissue Engineering
}

\section{Sílvia Vieira}

3B's Research Group, AvePark - Parque de Ciência e Tecnologia, Zona Industrial da Gandra, Barco, Guimarães 4805-017 Portugal

ICVS/3B's - PT Government Associate Laboratory, Braga, Guimarães Portugal

\section{Stephanie Vial}

3B's Research Group, AvePark - Parque de Ciência e Tecnologia, Zona Industrial da Gandra, Barco, Guimarães 4805-017 Portugal

ICVS/3B's - PT Government Associate Laboratory, Braga, Guimarães Portugal

\section{Rui L. Reis}

3B's Research Group, AvePark - Parque de Ciência e Tecnologia, Zona Industrial da Gandra, Barco, Guimarães $4805-017$ Portugal

ICVS/3B's - PT Government Associate Laboratory, Braga, Guimarães Portugal

\section{J. Miguel Oliveira}

3B's Research Group, AvePark - Parque de Ciência e Tecnologia, Zona Industrial da Gandra, Barco, Guimarães $4805-017$ Portugal

ICVS/3B's - PT Government Associate Laboratory, Braga, Guimarães Portugal

DOI 10.1002/btpr.2469

Published online 00 Month 2017 in Wiley Online Library (wileyonlinelibrary.com)

Tissue engineering (TE) envisions the creation of functional substitutes for damaged tissues through integrated solutions, where medical, biological, and engineering principles are combined. Bone regeneration is one of the areas in which designing a model that mimics all tissue properties is still a challenge. The hierarchical structure and high vascularization of bone hampers a TE approach, especially in large bone defects. Nanotechnology can open up a new era for TE, allowing the creation of nanostructures that are comparable in size to those appearing in natural bone. Therefore, nanoengineered systems are now able to more closely mimic the structures observed in naturally occurring systems, and it is also possible to combine several approaches - such as drug delivery and cell labeling - within a single system. This review aims to cover the most recent developments on the use of different nanoparticles for bone TE, with emphasis on their application for scaffolds improvement; drug and gene delivery carriers, and labeling techniques. (c) 2017 American Institute of Chemical Engineers Biotechnol. Prog., 000:000-000, 2017

Keywords: nanoparticles, bone tissue engineering, scaffolds, drug and gene delivery, imaging

\section{Introduction}

Tissue engineering and regenerative medicine (TERM) aims to conjugate engineering and biological properties to create functional substitutes for damaged and diseased tissues. ${ }^{1}$ Ideally, these structures would be capable of restoring, maintaining, or even improving tissue function. The strategy used on TERM research combines three essential elements scaffolds, stem cells, and growth factors - to produce a tissue engineered construct. Scaffolds provide the support for cell growth and tissue formation. For that, they are seeded with stem cells. These cells have the potential to differentiate and form the new tissue. Growth factors are also included as they regulate the differentiation and proliferation processes. The so-called tissue engineering triad, represented in Figure 1 , represents the whole strategy of TERM.

Correspondence concerning this article should be addressed to J. M. Oliveira at miguel.oliveira@dep.uminho.pt.
Bone tissue regeneration is one of the greatest challenges for TERM. The anatomical complexity of bone, allied with the high mechanical stress to which it is exposed, makes it unique, and almost impossible to replicate. Nevertheless, some strategies have been exploited, with positive results. Nanotechnology has made it possible to create structures within the same size as those that constitute naturally occurring bone, opening a new era for TERM. Hence, nanoparticles (NPs) can be used to modify scaffolds properties, leading to enhanced characteristics such as superior mechanical properties ${ }^{2-5}$ and osteointegration, osteoconduction, and osteoinduction. $^{2,6-9}$ Moreover, NPs can be applied to deliver drugs in a controlled and dependent manner, either systemically or locally. ${ }^{10-18}$ In another approach, NPs can be used to label cells, namely stem cells, enabling the continuous cell tracking and monitoring of its fate. ${ }^{19-23}$ This versatility is mostly a result of wide range of approaches for NPs functionalization. Antibodies, labeling probes, hydrophobic or hydrophilic molecules, DNA, and/or oligonucleotides are 


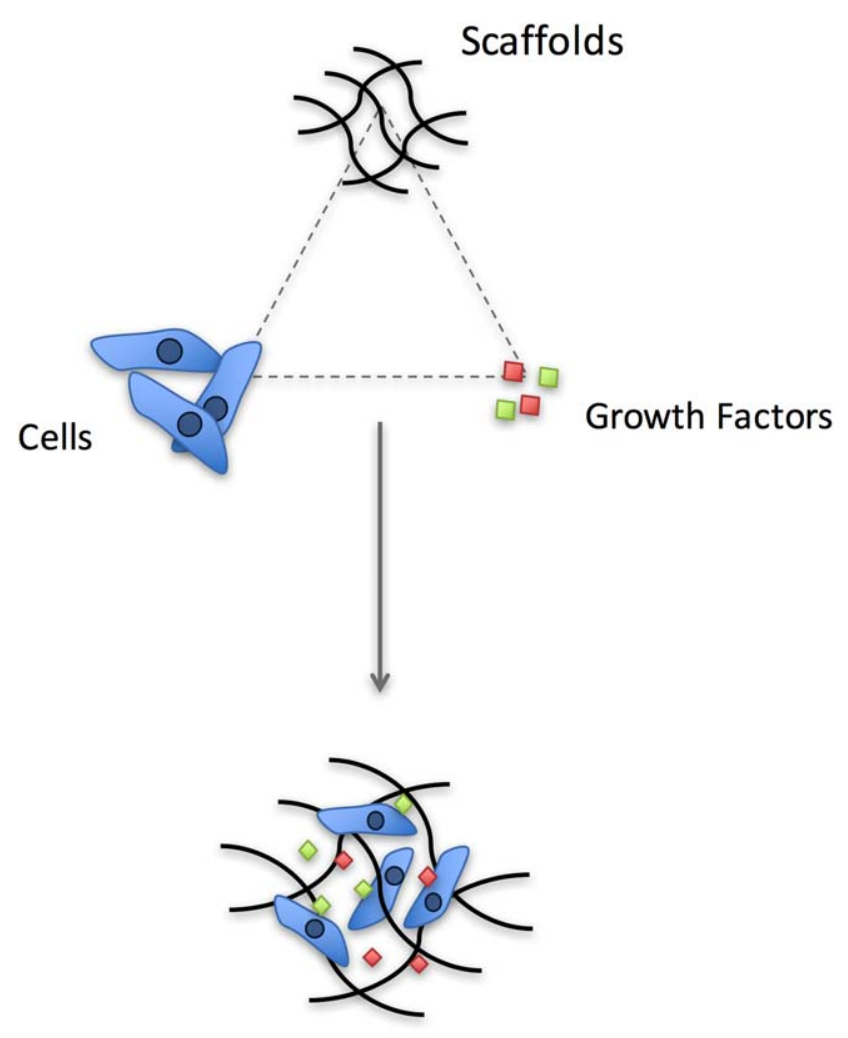

\section{TE construct}

Figure 1. Tissue engineering triad.

some of the molecules that can be linked to NPs, allowing a tailored application for the desired purpose. ${ }^{24}$ Although there are no applications for bone TERM using nanoparticles currently on market, the number of in vitro and in vivo studies in the last years reveals the great potential of this technology. This review will discuss the application of NPs in bone TERM, focusing on their use in scaffold improvement, delivery carriers, and cell labeling.

\section{Types of Nanoparticles}

Nanoparticles (NPs) of distinct nature are now available for research purposes and in the clinics, and the efforts to produce superior ones are ongoing. The most used NPs for bone TERM are schematically represented in Figure 2, along with their advantages and disadvantages.

\section{Organic NPS}

Liposomes. Liposomes are vesicles composed of one or more concentric bilayers, (lamellae) of natural nontoxic phospholipids. Each layer surrounds an aqueous compartment, where the head polar groups of phospholipids are in contact with aqueous phases while the hydrophobic parts are packed together (schematic representation in Figure 2, liposomes). Alec D. Bangham, who first introduced this type of particles in mid-1960s, described liposomes as "simply the vesicles which form spontaneously when isolated natural cell membrane phospholipids are shaken in water."25 Taking advantage of this characteristic, the author used the liposomes as model for the cell membrane, but nowadays these particles are also used in a wide range of applications, as recently reviewed, ${ }^{26,27}$ including drug delivery and imaging. Liposomes properties are affected by several parameters, such as lipid composition and organization, surface charge, preparation method, and size. ${ }^{28}$ The lipid composition determines the charge and fluidity of the bilayer and its sensitivity to external stimuli. The preparation methods affect the selfassembly of phospholipids, leading to different types of liposomes, which can be classified by their size and lamellarity. ${ }^{29}$

Commonly, liposomes are used as vehicles in delivery and/or targeting systems. For that end, it is necessary to incorporate the desired molecules inside the liposome structure. Such process can be performed in two possible ways, considering the nature of the cargo to include. If the molecule is hydrophobic, it is mixed with an organic solvent, and it will be integrated inside the hydrophobic part. But when the cargo is hydrophilic, it must be added as an aqueous solution, being retained in liposome inner part. ${ }^{30}$ Liposome size is also a particularly important parameter that directly affects the circulation half-life time. In fact, liposomes can vary from very small particles to large ones, that is, from few nanometers up to micrometers. Specifically, liposomes within the nanoscale range can be administrated along with drugs, or with other types of NPs, as reviewed by W. Al-Jamal et al. ${ }^{31}$ A drawback of these strategies is a fast recognition of liposomes by the reticuloendothelial system, which speeds up the process of their elimination from the bloodstream. This phenomenon can be reduced by using stealth liposomes, that is, liposomes coated with hydrophilic biocompatible polymers, such as poly(ethylene glycol) (PEG). ${ }^{32}$ Because they are highly biocompatible, biodegradable, and show a reduced toxicity, liposomes are considered as a suitable strategy for clinical applications. Moreover, it is possible to functionalize liposomes to be responsive to certain stimuli such as $\mathrm{pH}$, light, or enzyme cleavage. Together, these are great advantages as compared to other systems, which made the liposomes the most clinically established nanometer-scale systems, with several formulations being already commercialized. $^{28}$

Polymeric NPs. Owing to their bulk physical properties, tunable architecture, and biodegradability, polymers have been attracting much attention in recent years. The synthesis methods of polymers are flexible, and the polymer chains can usually be functionalized with a wide range of molecules. In this regard, the final polymers can present distinct compositions and properties, envisioning a wide range of applications and strategies. ${ }^{24}$ Usually, polymeric NPs are spherical with a diameter of approximately $100 \mathrm{~nm}$, but this dimension can be tuned, depending on their final application. Moreover, different applications may employ diverse architectures, changing NPs' physicochemical properties. Up to now, polymers are being used to produce polymeric micelles, ${ }^{33}$ nanofibers, ${ }^{34}$ and spherical NPs, ${ }^{35}$ either nanocapsules or nanospheres (Figure 2, polymeric NPs). Other structures with higher level of complexity can also be obtained by the self-assembling of responsive block copolymers, as reviewed by others. ${ }^{36}$

Another advantage of polymeric NPs is related to their unique high drug loading capability. Organic and inorganic molecules can be physically dissolved, dispersed, or linked by covalent interactions with the polymeric elements. ${ }^{24}$ Therefore, these carriers are now being used for transport 


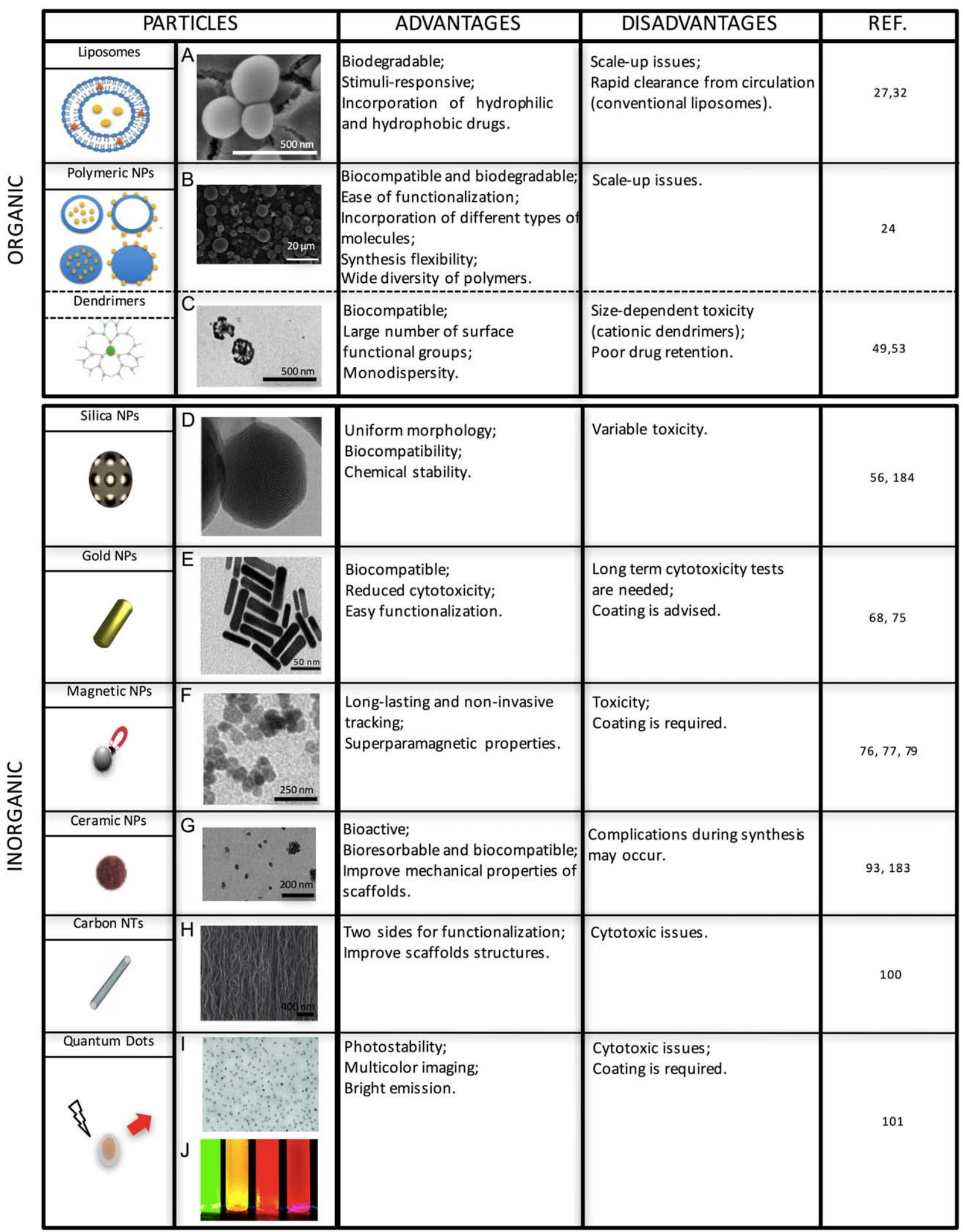

Figure 2. Insight of the different nanoparticles current used on bone tissue engineering research.

Electron microscopy images show the morphology of each type of particle. SEM images of liposomes (A, adapted from Ref. 144, with permission from John Wiley \& Sons) and polyester NPs (B, adapted from Ref. 139, with permission from John Wiley \& Sons). TEM images of dendrimers (C, adapted from Ref. 142, with permission from Elsevier), mesoporous silica NPs (D, adapted from Ref. 148 with permission from John Wiley \& Sons), gold NPs (E), SPIOs (F, adapted from Ref. 172), bioactive glass NPs (G, adapted from Ref. 121 with permission from Elsevier), carbon NTs ( $\mathrm{H}$, adapted from Ref. 181 with permission from John Wiley \& Sons), and QDs (I, adapted from Ref. 104 with permission from SAGE Publications). $\mathrm{J}$ is a representation of aqueous solutions of 525, 565, 585, and 605 quantum dots (left to right) under ultraviolet (UV) light (adapted from Ref. 104 with permission from SAGE Publications). 
and delivery of molecules in several fields, such as vaccination, cancer, inflammation, neurologic pathologies, and tissue regeneration. $^{24,37,38}$ There are numerous methods to synthesize polymer-based NPs, applied in accordance with the employed polymeric materials. ${ }^{24}$ For natural polymers, such as proteins and polysaccharides, the desolvation process ${ }^{39}$ and gelation ${ }^{40}$ are respectively preferred. For self-assembly of polymers in aqueous solution, emulsion-solvent evaporation, ${ }^{41}$ nanoprecipitation, ${ }^{42}$ and salting-out techniques are the most commonly used. ${ }^{24}$ Similar to other nanoparticle systems, polymer-based NPs can be functionalized to perform active targeting. The functionalization process can be done before or after the assembly process. Generally, the decision is driven by the size of the ligand to be attached. Small ligands, such as small organic molecules or small peptides, can be linked prior to the assembly or after nanoparticle formation, at its surface. ${ }^{43,44}$ On the other hand, bulky ligands such as polypeptides, proteins, or antibodies-are linked mostly at the surface of performed nanocarriers, considering that the secondary structure of these molecules is often denatured by solubilization in organic solvents. ${ }^{45}$

Dendrimers. The first dendrimers were reported in the late 1970s, by Vögtle group, ${ }^{46}$ followed in the early $1980 \mathrm{~s}$ by the work of Tomalia et al. ${ }^{47}$ It appeared as a very versatile and tunable particle, with a tree-like structure, branching out from a central core and subdivided into hierarchical branch units, ending with external capping units (Figure 2, dendrimers). These spherical, biocompatible, and biodegradable polymeric-based NPs possess a large number of surface functional groups, leading to a very versatile functionalization for a considerable number of applications. ${ }^{48}$ The core usually consists of an amine, although sugar or other molecules can also be used, with multiple identical reaction sites where two monomers bind, making a generation. ${ }^{49}$ In addition to cargo binding, the peripheral polar functional groups endow physicochemical properties to dendrimers that can be used to improve targeted drug delivery. That includes enzymatic, $\mathrm{pH}$, temperature, light, solvent, and ionic strength sensitivity, with configuration changes as a result of interactions between particles and the medium. ${ }^{50}$ Thus, it is possible to control cargo release, based on environmental conditions.

Dendrimers are commonly used for targeted drug delivery purposes, ${ }^{51}$ with an improvement on drug solubility. ${ }^{52}$ Although the monodispersity of dendrimers provides reproducible results and pharmacokinetics on clinical trials, ${ }^{49}$ they still have some drawbacks, such as cytotoxicity and poor drug retention within the dendrimer branches. Moreover, for positively charged dendrimers, such as poly(amido amine) (PAMAM) and poly(ethylenimine) (PEI), the cytotoxicity is proportional to the generation number. For instance, a first generation (G1) PAMAM dendrimer has approximately $22 \AA$ in diameter and eight surface groups. By increasing one generation, to $\mathrm{G} 2$, the diameter rises to $29 \AA$ but the number of surface groups grows exponentially to 16 . Thence, an increase in dendrimers' generation highly increases the number of positive charges available to interact with cells membrane, causing their disruption. ${ }^{53}$

\section{Inorganic NPs}

Inorganic nanomaterials are also being exploited for biomedical applications. Within this field, silica NPs, metallic NPs (such as magnetic, gold, or silver NPs), bioceramic
NPs, carbon nanotubes, and quantum dots are the most promising and will be herein discussed.

Silica NPs. Silica is known to be biocompatible, with an excellent chemical stability and defined surface properties. ${ }^{54,55}$ Hence, this material has been used for a plethora of biomedical applications, such as imaging and drug delivery, ${ }^{56}$ either itself or as a coating of other compounds. ${ }^{54}$ SiNPs can be synthesized by the Stöber method, through hydrolysis of silane, and the size can be tuned by varying the ratios of tetraethylorthosilicate (TEOS), ammonium hydroxide, and deionized water. ${ }^{57}$ Depending on their final use, silica NPs can be synthesized not only as bulk silica particles $(\mathrm{SiNPs})^{55}$ but also as core/shell silica NPs $(\mathrm{C} / \mathrm{S}$, SiNPs) ${ }^{56,58}$ and mesoporous silica NPs (MSNPs). ${ }^{56} \mathrm{C} / \mathrm{S}$, SiNPs are often used in imaging agent delivery. ${ }^{56}$ The silica shell protects the core, composed of imaging agents like fluorescent probes, decreasing the extent of photobleaching and enabling long-term monitoring of the labeled material. ${ }^{58}$ Similarly to SiNPs, C/S, SiNPs can also be constructed with tunable size, through a reverse microemulsion method. ${ }^{59}$ For controlled release applications, MSNPs have aroused significant interest. First, one can consider their tunable particle and pore size as well as their unique pore structure, high surface area, and large pore volume. That is a consequence of MSNPs morphology, as these particles are formed by hundreds of mesopores, in a honeycomb-like porous structure. Therefore, MSNPs are able to absorb/encapsulate large amounts of biomolecules. ${ }^{54}$ Second, MSNPs display an improved resistance to heat, $\mathrm{pH}$, mechanical stress, and hydrolysis-induced degradations. Finally, MSNPs are characterized by a chemical and thermal stability, nontoxic nature and simple fabrication, ${ }^{60}$ advantageous for biomedical applications.

MSNPs synthesis can be performed in several ways to get particles with different sizes and morphologies. As an example, the fluorocarbon-surfactant-mediated synthesis method, reported by Y. Han et al., ${ }^{61}$ yields particles with sizes between 50 and $300 \mathrm{~nm}$ and with distinct types of mesostructures, as 3D cubic, 2D hexagonal, foam-like, and disordered.

To control particle size and morphology and to improve structural order, J. Gu et al. ${ }^{62}$ added ethylene glycol to the synthesis process. In another approach, K. Möeller et al. ${ }^{63}$ were able to synthesize colloidal mesoporous silica with high yields by replacing the common base $\mathrm{NaOH}$ by the poly alcohol triethanolamine (TEA). The authors found that the amount of TEA added to the system controls the size of the resulting NPs. As a result, these particles exhibit unique pore geometry, because the pores grew radially from the center to the periphery, with large pore volume and size comprised between 50 and $100 \mathrm{~nm}$. Considering the bigger pore volume, such particles can be applied on drug delivery purposes, as more cargo can be included in the devoid volume.

Metallic NPs. Gold NPs. Metallic NPs exhibit unique characteristics, different from the bulk material, which are a direct consequence of the quantic effect. ${ }^{64}$ Among this type of NPs, gold NPs have arisen as an option for many biotechnology applications. Drug delivery, biosensing, bioimaging, and photothermal therapy are some of the areas where these particles can be applied. ${ }^{65-68}$ Such versatility is explained by the number of possible surface modifications, optical properties, biocompatibility, and reduced 
toxicity as compared to other metallic particles. ${ }^{68}$ Gold NPs can be synthesized with diverse shapes such as spheres, ${ }^{69}$ rods, ${ }^{70}$ star-like, ${ }^{71}$ and cages. ${ }^{66}$ The combination of gold NPs with other compounds such as silica, resulting on core-shell NPs, is also common. ${ }^{72}$ As a characteristic of gold NPs, the surface plasmon resonances (SPR) are verified on all the referred conformations, meaning that is possible to evaluate some of their properties, such as diameter or shape, through UV-vis spectra analysis. Given that SPR bands are influenced by small changes on size, shape, surface ligands, charge, temperature, and aggregation, it presents great advantages for biomedical applications, such as biosensing and diagnosis. ${ }^{73}$ Gold NPs are also interesting for bioimaging processes, as they can be tuned to absorb in the near infrared range, thus leading to enhanced deep-tissue visualization by imaging techniques. Also, the high atomic number can induce strong X-ray attenuation resulting in an enhanced computed tomography contrast. ${ }^{74}$ Although gold NPs are considered safer than other metallic NPs, it is still necessary to examine their biocompatibility, biodistribution, bioelimination, and environmental impact before their production on a large scale for in vivo applications. ${ }^{75}$

Magnetic NPs. Magnetic elements such as iron, nickel, cobalt, and their oxides, with a nanometer size, are being used in different biomedical applications. Detailed information about the most common uses of magnetic NPs (MNPs) were recently reviewed. ${ }^{76,77}$ This group of NPs includes metallic, bimetallic, magnetic cationic liposomes, and superparamagnetic iron oxide NPs (SPIONs). ${ }^{78}$ Similar to other nanosystems, their surface can be functionalized to recognize specific targets. Hence, they can be used for imaging processes, cell tracking and isolation, biosensors, guided drug and gene delivery, 3D cell organization, and hyperthermia. ${ }^{76}$ Although some MNPs, such as nickel ferrites, have shown potential toxicity affecting cell proliferation and viability, ${ }^{79}$ some of the iron oxide MNPs become biocompatible when coated with specific surface modifiers. ${ }^{80}$ Still, there is much research to be performed to fully characterize these particles and understand their behavior and safety profile in vivo.

Bioceramics and Bioactive Glass NPs. Bioceramics, glasses, and glass-ceramics are characterized as materials with an inorganic/nonmetallic composition that are biocompatible and applicable for biomedical uses. ${ }^{81}$ From a chemical perspective, these materials can be divided into two classes: (i) calcium phosphate groups, that includes hydroxyapatite and $\beta$-tricalcium phosphate; and (ii) others, such as alumina, bioactive glass systems, and bioactive glassceramic systems. $^{81}$

Bioceramic NPs such as hydroxyapatite (HAp), calciumdefective HAp (CDHA), and tricalcium phosphate have been combined with natural $^{82}$ and synthetic polymers, ${ }^{83,84}$ forming nanocomposite materials. ${ }^{85,86}$ These hybrid biomaterials hold superior mechanical properties ${ }^{87}$ that can be used to improve tissue regeneration strategies, mostly the ones related to bone diseases. Thence, bioceramic NPs can be applied to improve scaffolds' performance, and also as a controlled delivery system for biologically active substances like drugs $^{88}$ or genetic material. ${ }^{89}$

Bioactive glasses are amorphous silicate-based materials that can form a chemical bond with bone tissue. The first bioactive glass, the Bioglass ${ }^{\circledR},{ }^{90}$ was discovered in 1969 by Larry Hench et al. ${ }^{91}$ The silicon component of this material is released when the bioactive glass is implanted, inducing the formation of a calcium deficient hydroxyapatite layer on its surface. This layer interacts with collagen fibrils of damaged bone, allowing bioactive glass to bond to the surrounding tissue. ${ }^{92}$

Although the synthesis of monodisperse bioactive glass NPs is not a simple process, these particles have attracted great deal of attention from biological material researchers. ${ }^{85,93,94}$ As a result, similarly to bioceramics, bioactive glass NPs have been combined with different types of polymers, both synthetic ${ }^{95,96}$ and natural, ${ }^{97}$ to produce bioactive nanostructured polymeric composites with improved properties.

Carbon Nanotubes. Since their discovery in 1991, carbon nanotubes (CNTs) have been regarded as a potential tool for a variety of applications. In the biomedical field, researchers are working to evaluate their potential for drug delivery, theranostics, biosensing, microscopy, and reinforcement of composite materials. ${ }^{98}$ CNTs are graphitic hollow tubular structures, made by a sheet of carbon atoms connected by $\mathrm{sp}^{2}$ bounds, with excellent electrical properties and high mechanical and chemical stability. They can be composed by a single tube with a diameter range of 0.4 $2 \mathrm{~nm}$ (single-walled carbon nanotubes (SWCNT)) or by concentric walls, with an external diameter varying between 2 and $100 \mathrm{~nm}$ (multiwalled carbon nanotubes (MWCNT)). Their size is variable and they can be either conductive or nonconductive. Owing to their tubular structure, it is possible to functionalize these structures both from inside and outside, with two distinctive molecules for two different purposes. As aforementioned, CNTs usually have a high chemical stability which is a disadvantage for covalent functionalization process, as they require defective carbon atoms on the tubular structure. ${ }^{99}$ Regarding clinical applications, it is still necessary to perform deeper and standardized studies to understand their toxicity. Parameters such as shape, length, surface charge, diameter, purity, and agglomeration are considered the key-players in CNTs toxicity. ${ }^{100}$

Quantum Dots. Quantum dots (QDs) are colloidal semiconductor nanocrystals, ranging from 1 to $10 \mathrm{~nm}$. In each nanocrystal, a large fraction of atoms is at the surface, meaning a high surface area-to-volume ratio. The typical configuration of QDs is a core/shell structure of type II-VI, where the shell protects and improves the optical properties of the core. $\mathrm{CdSeS} / \mathrm{ZnS}, \mathrm{CdSe} / \mathrm{ZnS}$, and $\mathrm{CdTe} / \mathrm{ZnS}$ are the most common combinations for biological applications, ${ }^{101}$ namely bioimaging and bioanalysis. Advantageous optical properties of QDs over conventional fluorescent markers include their photostability and longer excited state lifetime, making them suitable probes for tracking dynamic processes over time and for long-term cell labeling. ${ }^{102,103}$ Moreover, these NPs are quite useful for multiplexed analysis and multicolor imaging, as it is possible to simultaneously excite and detect multiple colors of QDs using a single light source, as shown in Figure 2, (quantum dots). ${ }^{104}$ That arises from the fact that QDs exhibit broad absorption but narrow emission spectra. As the photoluminescence properties of the QDs are strictly related to their size, it is possible to control and select the emission spectra of the QD by tuning this property. ${ }^{105}$ Although they can be used in a wide range of biomedical applications, the latent toxicity of QDs could hinder their broad use. One of the concerns relies on the release of free cadmium ions by cadmium-containing QDs, causing cell death. ${ }^{106}$ Generation of reactive oxygen species has also been implicated as a 


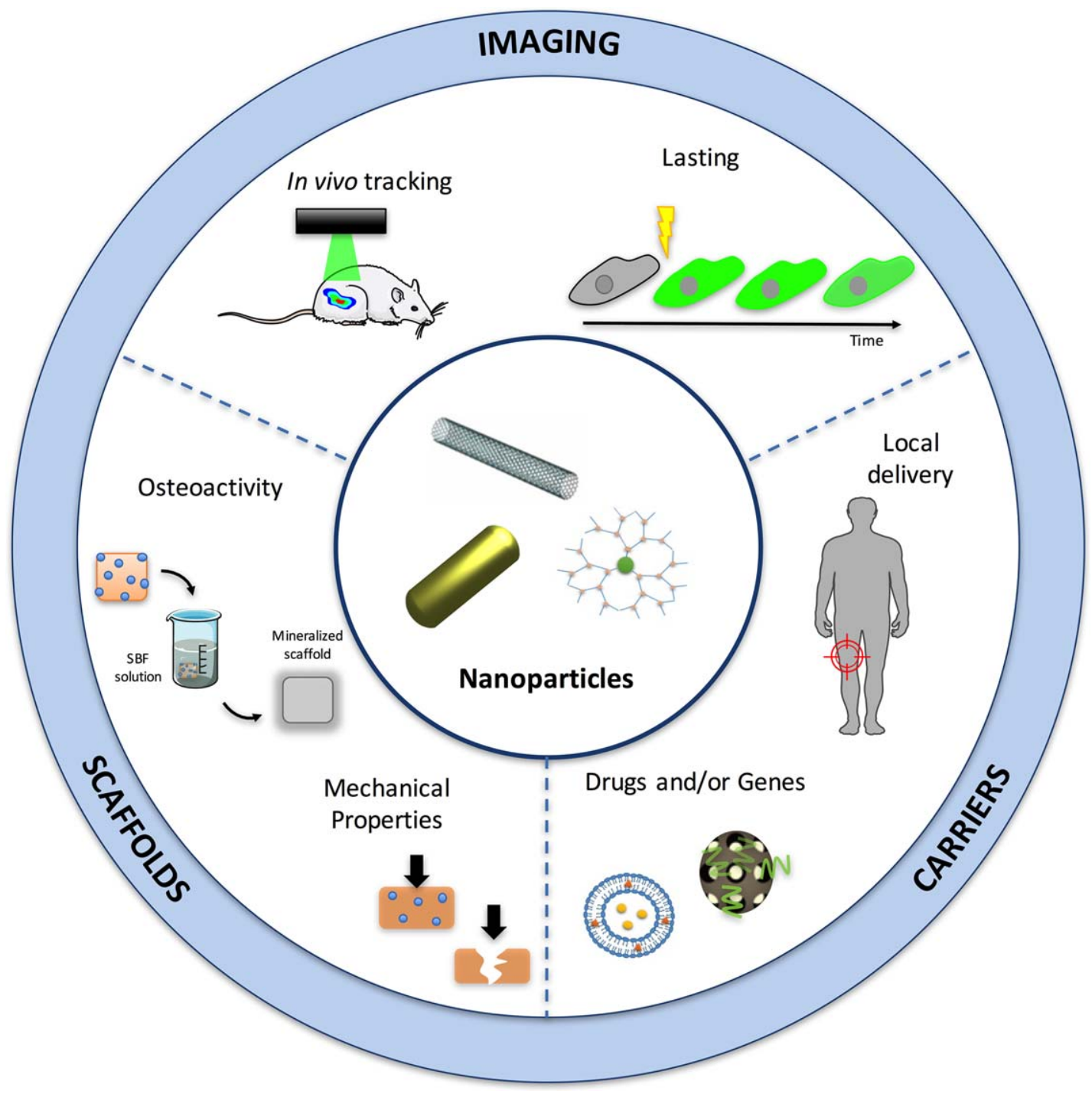

Figure 3. Main applications of NPs in the developments of scaffolds, carriers, and cell labeling.

(SBF, simulated body fluid.)

reason for QDs cytotoxicity, which is known to damage cellular proteins, lipids, and DNA. ${ }^{107}$ However, in more complex models such animal models, QDs seem to be safe. ${ }^{101,108}$ Such discrepancy can be explained by the dose. While cell studies are based on a constant QDs dose, in animal models only a fraction of the particles will interact with cells. Moreover, QDs suffer modifications after passage through the body, changing their size and surface chemistry. Such modifications can alter the degree of particle internalization, then changing the effective intracellular concentration and consequently the cytotoxic effects. ${ }^{109}$ It is also worth pointing out that, in most of the cases, QDs undergo minimal excretion, meaning that long-term toxicity could be a problem, but has not been established yet. ${ }^{108}$ Therefore, QDs toxicity is still an issue of much concern, and should be addressed using standardized and systematized protocols to avoid methodological variability, and should also use a case-by-case approach as distinct QDs formulations can trigger different biological responses. ${ }^{108}$ Other materials, such as silicon ${ }^{110}$ and carbon, ${ }^{111}$ are also being used to remove heavy metals from QDs formulations, thereby avoiding their deleterious effects.

\section{Applications for Bone TE}

NPs can be used as tools for bone TE through a wide range of applications - from drug delivery systems to the construction of biomimetic hierarchical scaffolds. Constructs can be improved, leading to multivalent systems that closely resemble the natural occurring ones. Drug and gene delivery can be performed specifically on a target area, increasing its efficiency, with less systemic effects. Moreover, with nanotechnology, the cell labeling techniques have become more specific and abiding, allowing noninvasive in vivo approaches for cell monitoring and tracking. These topics are schematically represented in Figure 3 and in the following subsections, they will be discussed in more detail.

\section{Scaffolds}

Several TE strategies are based on scaffolds properties, due to scaffolds' importance in providing architectural support for cell growth and establishing the appropriate regenerative niche. ${ }^{87}$ The major goal of scaffold-based strategies is to obtain an implant to replace the native tissue while 


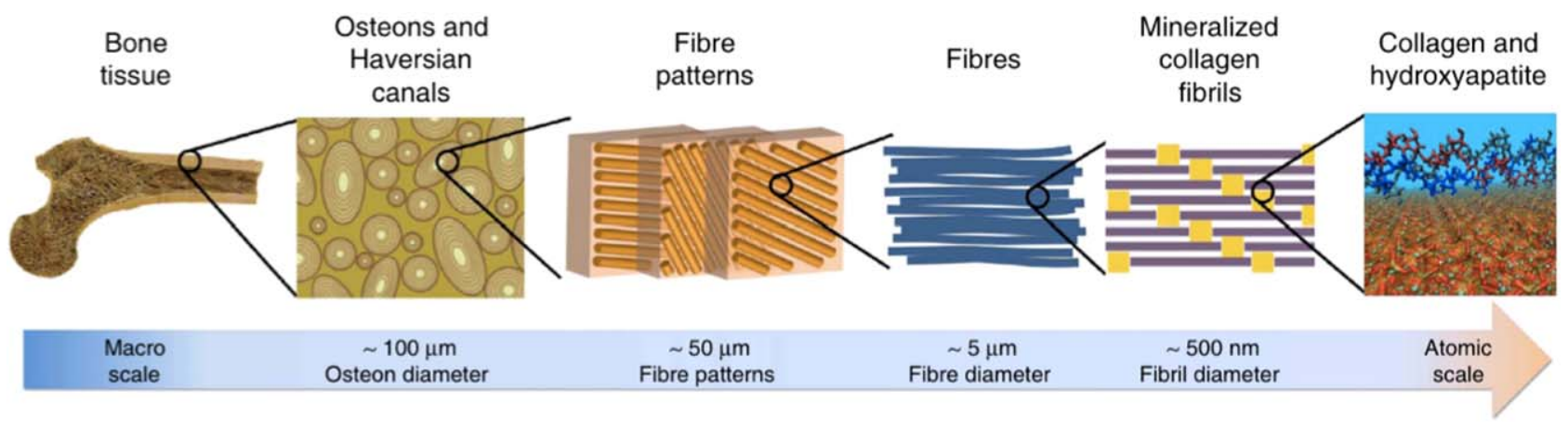

Figure 4. Bone hierarchical structure.

Reprinted with permission from Macmillan Publishers Ltd: Nature Communications. ${ }^{182}$

supporting the regeneration process without further complications. To achieve such goal, scaffolds should be threedimensional and highly porous, forming an interconnected pore network. Biocompatibility is also necessary along with a controlled degradation and resorption rate. The surface chemistry should allow cell attachment, proliferation, and differentiation and to be mechanically similar to tissues, at the implantation site. ${ }^{112}$ For bone regeneration, scaffolds should also be able to deliver physicochemical and mechanochemical cues and provide mechanical strength and support through suitable biophysical properties. ${ }^{87}$

From a TE perspective, bone is a complex nanocomposite, hierarchically organized, with an organic extracellular matrix, strengthened by inorganic calcium phosphate NPs, HAp crystals, ${ }^{113}$ as depicted in Figure 4. Hence, boneinspired hybrid scaffolds, that is, organic and inorganic portioned, have been considered as a potential approach for bone regeneration. As polymers are easily modified and functionalized, they are commonly used as the organic portion, mostly as nanofibers. This configuration is beneficial for bone tissue formation because it mimics the type I collagen fibers found in natural bone. ${ }^{114}$ However, their compatibility to bone tissue and their mechanical strength is often inferior when compared to calcium phosphate ceramics. As summarized in Table 1, diverse types of NPs have been used to tackle this problem, with promising results.

Incorporation of calcium phosphate NPs, with similar size and functionality as the nanosized inorganic ceramic particles that are naturally present in bone, is a way to improve scaffolds properties. This strategy often leads to an increased osteocompatibility and mechanical performance of such nanocomposites over purely polymeric bone substitutes. $^{6,115,116}$ Qian et al. ${ }^{8}$ compared the behavior of a biomorphic poly(lactic-co-glycolic acid) (PLGA) scaffold with and without HAp NPs. The presence of particles had a beneficial effect in several parameters, such as cell attachment, proliferation, and differentiation of MC3T3-E1 cells (Figure 5). Chae et al. ${ }^{9}$ designed alginate nanofibers with a uniform deposition of HAp nanocrystals, avoiding the aggregation that occurs when the conventional mechanical blending/electrospinning method is used. This uniform distribution at polymer surface contributed for a stronger attachment of osteoblast cells to the scaffold when HAp NPs where mixed with the alginate matrix. Indeed, osteoblasts acquired a spindle-shape form with filopodia formation on the HAp/ alginate scaffolds, while on pure alginate, cells were round and flattened. This effect was also observed by others and the positive effect of HAp NPs on cell focal adhesion formation and protein absorption were already reported. ${ }^{117}$ In another work, HAp NPs were doped with gadolinium and then used within a polycaprolactone (PCL) nanofibrous scaffold. Hence, HAp acquired a dual purpose, both improving bone conductivity and acting as a magnetic resonance contrast agent. ${ }^{118}$ The incorporation of $30-40 \mathrm{~nm}$ sized HApdoped NPs rendered scaffolds with different properties, as compared to pure PCL. The contact angle was lower $\left(130.8 \pm 1^{\circ}\right.$ vs. $\left.146.2 \pm 0.6^{\circ}\right)$, which is a consequence of the addition of hydrophilic HAp NPs. Tensile stress failure tests showed that the scaffolds with doped HAp NPs present a superior mechanical strength, with a stress at failure of 3.33 MP, while pure PCL was found to be $1.3 \mathrm{MPa}$. The authors hypothesized that this improvement is a result of the incorporation of HAp NPs, similar to what happens in native bone where HAp nanocrystals increase its stiffness and compressive strength. Moreover, the smaller diameter of PCL fibres, observed when HAp NPs were included, results in a decreased pore size that can also contribute for the strength improvement. The incorporation of HAp NPs also increased the protein absorption to the fibres $(11.5 \pm 0.38 \mu \mathrm{g} / \mathrm{mg}$ vs. $8.6 \pm 0.24 \mu \mathrm{g} / \mathrm{mg}$ after $8 \mathrm{~h}$ ) by creating an irregular surface on PCL. Human MSCs osteogenic differentiation was also improved, with an increase of ALP expression of approximately $43 \%$ in scaffolds with NPs compared with pure PCL. The RUNX2 protein was also expressed earlier on composite scaffolds, corroborating the osteogenic potential of these scaffolds. The introduction of gadolinium allowed the tracking of the engineered constructs in vitro, during cell culture. Without cells, the scaffolds had a poor contrast due to the hydrophobicity of PCL that hinder proton exchange. When cells start to grow, the contrast increased as PCL interacted with the lipid cell membrane, promoting the proton exchange with the contrast agent. The contrast peaked at day 14 and then decreased as minerals started depositing. Such behavior can be used to monitor cell differentiation on these scaffolds that displayed bone forming capacity and improved strength.

Silk fibroin (SF), combined with calcium phosphate NPs, is also being used as scaffold. L. Yan et al. ${ }^{82}$ have developed a new method for silk fibroin/nanosized calcium phosphate scaffolds with in situ synthesis, leading to a homogeneous distribution of the calcium phosphate NPs within the SF matrix. The resulting scaffold displayed higher porosity, osteoconductivity, and osteogenic potential. In vivo studies on rat femur showed that this scaffold induced new bone formation after 3 weeks of implantation, compared to bare SF scaffolds. ${ }^{119}$ Another approach was developed by Kim et al. ${ }^{3}$ to overcome the poorly controlled nanofiber structures 
Table 1. Summary of Recent Works with Scaffolds and NPs

\begin{tabular}{|c|c|c|c|c|c|c|}
\hline Application & Type of NP & Matrix & Concentration & Model & Outcome & Ref. \\
\hline \multirow[t]{21}{*}{ Scaffolds } & HAp & $\begin{array}{l}\text { Poly(ester } \\
\text { urethane) }\end{array}$ & $\begin{array}{l}10,20, \\
\text { and } 30 \mathrm{wt} \%\end{array}$ & $\begin{array}{l}\text { In vivo-dorsal } \\
\text { skinfold chamber } \\
\text { model (BALB/c } \\
\text { mice) }\end{array}$ & $\begin{array}{l}\text { Enhanced mechanical properties; } \\
\text { biocompatibility and vasculariza- } \\
\text { tion are not affected by the modi- } \\
\text { fication with HAp NPs. }\end{array}$ & 6,7 \\
\hline & HAp & Alginate & n.a. & $\begin{array}{l}\text { In vitro - rat calvarial } \\
\text { osteoblasts }\end{array}$ & $\begin{array}{l}\text { Well-dispersed HAp along the } \\
\text { matrix; improved cell adhesion. }\end{array}$ & 9 \\
\hline & HAp & PLLA & $5 \mathrm{wt} \%$ & $\begin{array}{l}\text { In vivo-femoral } \\
\text { condyle of sheep }\end{array}$ & $\begin{array}{l}\text { Improved bioactivity; better } \\
\text { mechanical properties. }\end{array}$ & 115 \\
\hline & CDHA & PLA & $\begin{array}{c}25 \% \\
\text { (CDHA ratio) }\end{array}$ & $\begin{array}{l}\text { In vitro-7F2 mouse } \\
\text { osteoblast cells }\end{array}$ & $\begin{array}{l}\text { Enhanced bioactivity; control of } \mathrm{pH} \\
\text { decrease (caused by PLA degra- } \\
\text { dation); faster PLA degradation; } \\
\text { improved cell growth. }\end{array}$ & 116 \\
\hline & HAp/PCL & $\mathrm{HAp} / \beta$-ТCP & n.a. (coating) & $\begin{array}{l}\text { In vitro-human } \\
\text { osteoblast-like } \\
\text { cells }\end{array}$ & $\begin{array}{l}\text { Better mechanical properties; } \\
\text { enhanced bioactivity; improved } \\
\text { differentiation profile. }\end{array}$ & 2 \\
\hline & HAp & PLGA & $5 \mathrm{wt} \%$ & $\begin{array}{l}\text { In vitro-MC3T3-E1 } \\
\text { cells }\end{array}$ & $\begin{array}{l}\text { Improved elastic modulus; higher } \\
\text { biocompatibility. }\end{array}$ & 8 \\
\hline & $\begin{array}{l}\text { Calcium } \\
\text { phosphate }\end{array}$ & Silk fibroin & $4-16 \mathrm{wt} \%$ & $\begin{array}{l}\text { In vitro- }- \text { L929 fibro- } \\
\text { blasts; in vivo- } \\
\text { wistar rat femur. }\end{array}$ & $\begin{array}{l}\text { Self-mineralization capacity; induc- } \\
\text { tion of higher amount of new } \\
\text { bone. }\end{array}$ & 82 \\
\hline & Bioactive glass & $\mathrm{HAp} / \beta$-ТCP & $1-90 \mathrm{wt} \%$ & $\begin{array}{l}\text { In vitro-primary } \\
\text { human bone- } \\
\text { derived cells }\end{array}$ & $\begin{array}{l}\text { Improvement of differentiation pro- } \\
\text { file; higher bioactivity; faster deg- } \\
\text { radation rate; induction of cell } \\
\text { differentiation. }\end{array}$ & 121 \\
\hline & Bioactive glass & Gelatin & $30 \mathrm{wt} \%$ & $\begin{array}{l}\text { In vivo-human air- } \\
\text { way fibroblast } \\
\text { cells; in vivo- } \\
\text { New Zealand white } \\
\text { rabbit. }\end{array}$ & $\begin{array}{l}\text { Helped in vivo growth and healing } \\
\text { of bone. }\end{array}$ & 120 \\
\hline & Bioactive glass & PCL & $40 \mathrm{wt} \%$ & SBF immersion. & $\begin{array}{l}\text { Higher apatite-forming bioactivity; } \\
\text { increased elastic modulus. }\end{array}$ & 96 \\
\hline & Bioactive glass & Chitosan & $\begin{array}{l}10,30, \\
\text { and } 50 \mathrm{wt} \%\end{array}$ & SBF immersion. & $\begin{array}{l}\text { Improved mechanical properties, } \\
\text { namely compressive modulus and } \\
\text { strength; apatite formation-bio- } \\
\text { active scaffold }\end{array}$ & 97 \\
\hline & Bioactive glass & Alginate & $\begin{array}{l}0,10,20, \\
\text { and } 30 \mathrm{wt} \%\end{array}$ & $\begin{array}{l}\text { In vitro-rat bone } \\
\text { marrow mesenchy- } \\
\text { mal stromal cells; } \\
\text { in vivo-Sprague- } \\
\text { Dawley rats, sub- } \\
\text { cutaneous pockets; }\end{array}$ & $\begin{array}{l}\text { Higher cell infiltration in vivo; } \\
\text { enhanced osteogenic } \\
\text { differentiation. }\end{array}$ & 123 \\
\hline & CNTs & $\begin{array}{l}\text { Bioactive } \\
\text { glass }\end{array}$ & $\begin{array}{l}0,0.1,0.25 \text {, } \\
\text { and } 0.5 \mathrm{wt} \%\end{array}$ & n.a. & $\begin{array}{l}\text { Higher compressive strength and } \\
\text { elastic modulus with } 0.25 \mathrm{wt} \% \\
\text { bioactive glass. }\end{array}$ & 4 \\
\hline & CNTs & Chitosan & $\begin{array}{l}0,0.1,0.5 \\
\text { and } 1 \%\end{array}$ & $\begin{array}{l}\text { In vitro-murine } \\
\text { osteoblasts. }\end{array}$ & $\begin{array}{l}\text { Improved mechanical properties; no } \\
\text { cytotoxicity. }\end{array}$ & 5 \\
\hline & CNTs & PLGA & $\begin{array}{l}1,3, \text { and } \\
5 \mathrm{mg} / \mathrm{mL}\end{array}$ & $\begin{array}{l}\text { In vitro-MC3T3-E1 } \\
\text { cells. }\end{array}$ & $\begin{array}{l}\text { Improved mechanical strength; } \\
\text { increased surface roughness; } \\
\text { higher cell attachment, prolifera- } \\
\text { tion, and differentiation. }\end{array}$ & 124 \\
\hline & CNTs & Chitosan/HAp & $0-5 \mathrm{wt} \%$ & $\begin{array}{l}\text { In vitro-MC3T3-E1 } \\
\text { cells. }\end{array}$ & $\begin{array}{l}\text { Improved mechanical properties; } \\
\text { higher cell proliferation. }\end{array}$ & 125 \\
\hline & CNTs & PLGA & $1 \mathrm{wt} \%$ & $\begin{array}{l}\text { In vitro-MC3T3-E1 } \\
\text { cells. }\end{array}$ & $\begin{array}{l}\text { Improved mechanical properties; } \\
\text { higher cell proliferation. }\end{array}$ & 127 \\
\hline & Magnetic/HAp & PLA & $8 \mathrm{wt} \% / 31 \mathrm{wt} \%$ & $\begin{array}{l}\text { In vivo-rabbit lum- } \\
\text { bar transverse } \\
\text { defect. }\end{array}$ & $\begin{array}{l}\text { Faster bone tissue formation due to } \\
\text { supermagnetic responsive } \\
\text { properties. }\end{array}$ & 129 \\
\hline & Magnetic & HAp & $0.2-2 \mathrm{wt} \%$ & $\begin{array}{l}\text { In vitro-MC3T3-E1 } \\
\text { and ROS 17/2.8 } \\
\text { cells. }\end{array}$ & $\begin{array}{l}\text { Magnetic response; superior bio- } \\
\text { compatibility, cell proliferation, } \\
\text { and differentiation. }\end{array}$ & 130 \\
\hline & Silica & PCL & $\begin{array}{c}1,3 \text {, and } \\
5 \text { layers of NPs }\end{array}$ & $\begin{array}{l}\text { In vitro-hFOB } 1.19 \\
\text { cells. }\end{array}$ & $\begin{array}{l}\text { Increased surface roughness and } \\
\text { wettability; one layer of NPs is } \\
\text { indicated to have better cell per- } \\
\text { formance; enhanced osteoconduc- } \\
\text { tivity, and osteoinductivity. }\end{array}$ & 55 \\
\hline & AuNPs & Gelatin & 1,5 , and $14 \mu \mathrm{g}$ & $\begin{array}{l}\text { In vitro-ASCs; in } \\
\text { vivo-New Zealand } \\
\text { white rabbit parie- } \\
\text { tal bone defect. }\end{array}$ & $\begin{array}{l}\text { Better differentiation profile (dose } \\
\text { dependent). }\end{array}$ & 133 \\
\hline
\end{tabular}

ASCs, adipose-derived stem cells; AuNPs, gold nanoparticles; CDHA, calcium-deficient hydroxyapatite; CNTs, carbon nanotubes; HAp, hydroxyapatite; n.a., not applicable; NPs, nanoparticles; PCL, polycaprolactone; PLA, polylactic acid; PLLA, poly-L-lactic acid; PLGA, poly lactic-co-glycolic acid; SBF, simulated body fluid; TCP, tricalcium phosphate. 

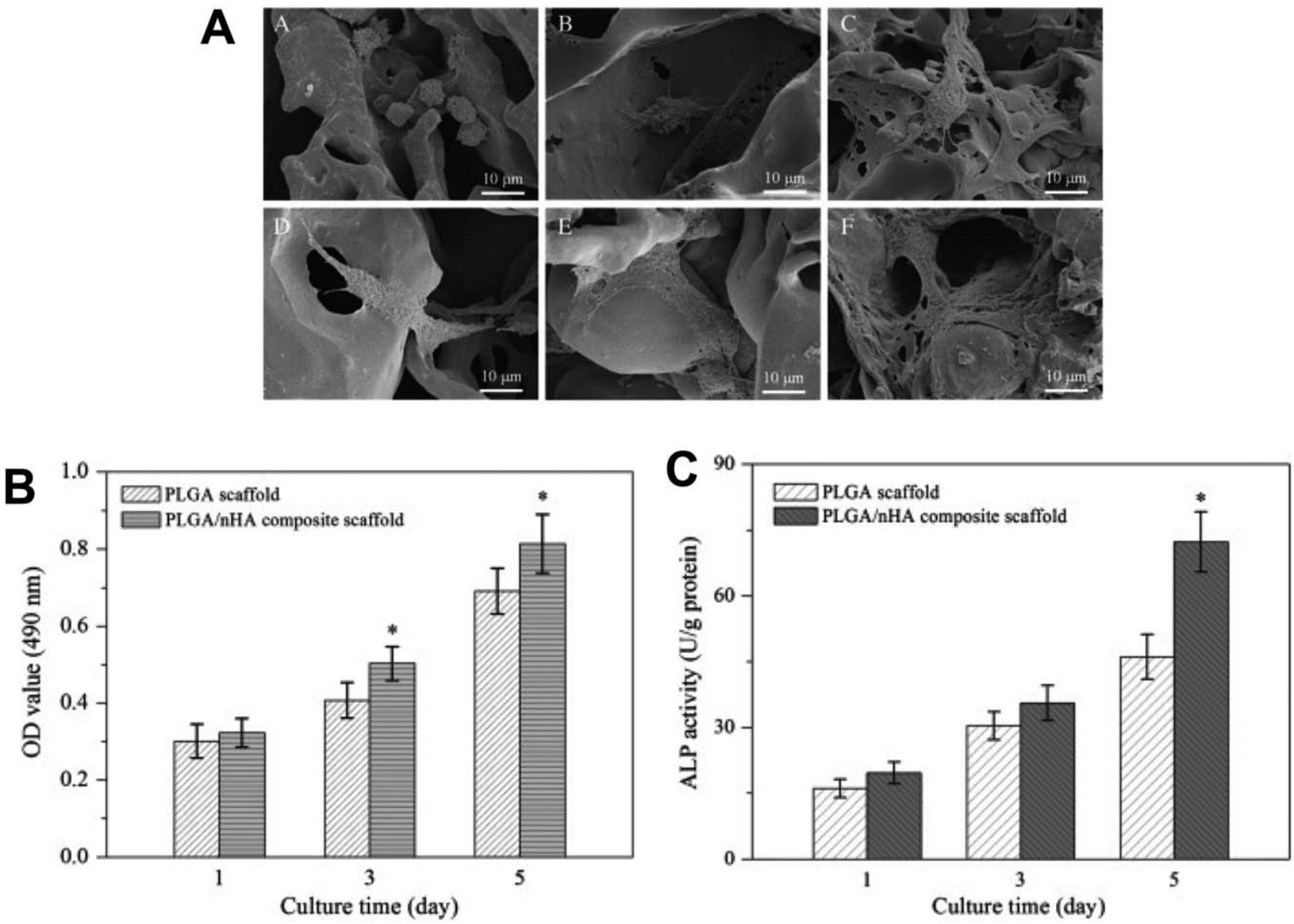

Figure 5. Effect of HAp NPs on MC3T3-E1 cells.

Panel A: SEM images of MC3T3-E1 cells on PLGA scaffold (A, B, C) and PLGA/HAp NPs composite (D, E, F) scaffolds cultured for 1 (A, D), 3 (B, E) and 5 (C, F) days. Panel B: Metabolic activity (optical density values) for MC3T3-E1 cells on PLGA and PLGA/HAp NPs composite scaffolds after different culture periods (days 1, 3, and 5). The symbol * indicates a significant difference. Panel C: Levels of ALP activity of MC3T3E1 cells on PLGA and PLGA/nHA composite scaffolds after different culture periods (days 1,3, and 5). The symbol * indicates a significant difference. Adapted and reprinted from Ref. 8 with kind permission from Elsevier.

resulting from the electrospinning of liquid and particulatebased suspensions. The strategy involved the functionalization of HAp NPs with $\gamma$-glycidoxypropyltrimethoxysilane (GPTMS), which can react with side chains of SF, such as lysine, histidine, arginine, and tyrosine. Such modification led to a uniform dispersion and enhanced interfacial bonding between HAp and SF fibers, up to a concentration of $20 \%$ wt HAp. Regarding the mechanical properties, tensile testing of the composite scaffolds showed the peak strength at $20 \%$ wt HAp. Higher concentrations of HAp NPs disrupted the SF polymer chains, hampering the mechanical properties of the fibers. ${ }^{3}$

Composite scaffolds can also be reinforced by the addition of ceramic NPs. Roohani-Esfahani et al. ${ }^{2}$ studied the HAp NPs effects, specifically how their shape and size influences the properties of biphasic hydroxyapatite/ $\beta$-tricalcium phosphate (BCP) scaffolds. The scaffolds were coated with a nanocomposite layer of HAp NPs (with different shapes) embedded in PCL, or with a microcomposite layer. The authors found that needle shaped HAp NPs improved the compressive strength, elastic behavior, and bioactivity of the scaffolds. Moreover, between sphere-, rod-, and needleshaped HAp NPs, the incorporation of the last configuration led to a higher bioactivity, as shown in Figure 6 by apatite formation, and to a superior osteoblast differentiation profile. $^{2}$

Owing to their bioactive nature, bioactive glass NPs are also commonly used for bone TE. ${ }^{120-122}$ In a follow-up work of the above-mentioned, Roohani-Esfahani et al. replaced the HAp NPs by bioactive glass NPs to increase the degradation rate and to enhance the bioactivity of biphasic calcium phosphate scaffolds coated with HAp-PCL composites. ${ }^{121}$ This strategy also led to a significant increase of the gene expression of RUNX2 and bone sialoprotein in human osteoblast cells cultured for 7 days. Hafezi et al. designed and tested in vivo a gelatin/bioactive glass NPs scaffold. ${ }^{120}$ After 12 weeks of application in an ulna defect on rabbits, radiographs of the defect site have shown that the composite scaffold helped bone growth and healing. ${ }^{120}$ Recently, Pourhaghgouy et al. reinforced chitosan scaffolds with bioactive glass NPs $(10,30$, and $50 \mathrm{wt} \%)$. The resulting nanocomposite scaffolds, produced by the freeze-casting technique, had a good interfacial bonding between the NPs and the polymeric matrix, which resulted in a structure with improved mechanical properties in regard to the compressive strength (from $34 \mathrm{kPa}$ of chitosan to 363,375 , and $419 \mathrm{kPa}$, respectively) and modulus (10.04, 10.43, and $10.77 \mathrm{MPa}$ versus $0.41 \mathrm{MPa}$ of chitosan). ${ }^{122}$ Buitrago et al. ${ }^{123}$ used the 

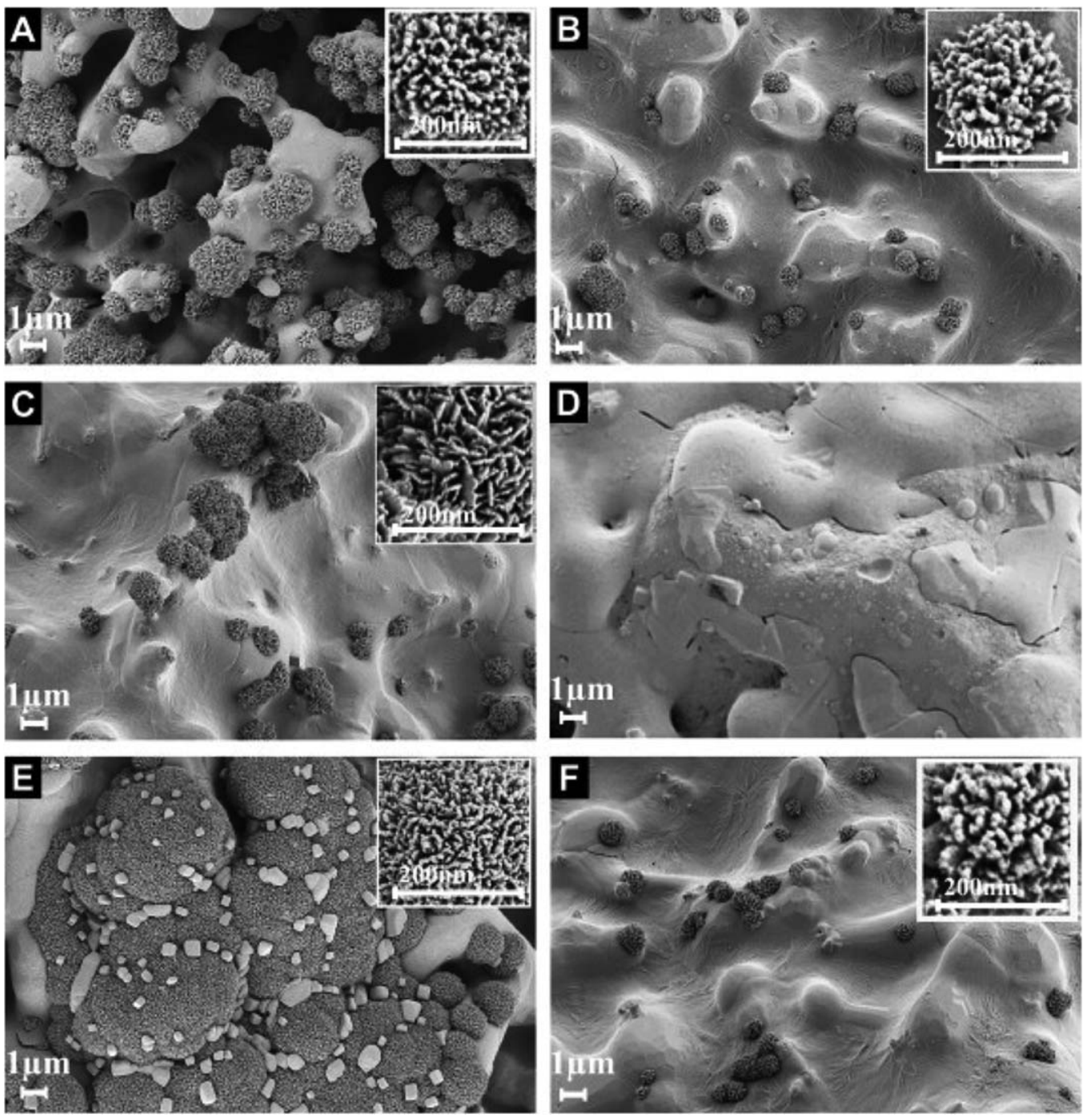

Figure 6. Effect o HAp NPs shape on composite scaffolds' bioactivity.

SEM images of the surface of prepared scaffolds after soaking in simulated body fluid (SBF) for 14 days; Hydroxyapatite/ $\beta$-tricalcium phosphate (BCP) (A); BCP plus coating with micron size HAp-PCL (B); BCP coated by PCL combined with spherical (C), needle shape (E), and rod (F) Hap NPs; BCP coated with PCL (D). Reprinted from Ref. 2 with permission from Elsevier.

bioactive glass NPs as nanoparticulate cues for bone TE in a core-shell fiber hydrogel system. The strategy relied on a collagen core surrounded by an alginate shell with NPs. In vitro osteogenic differentiation of rat MSCs encapsulated in the fiber core was assessed by alkaline phosphatase activity and gene expression of collagen I, bone-sialoprotein, and osteocalcin. The results show an enhanced osteogenic behavior in the presence of bioactive glass NPs, and a higher in vivo cell infiltration. These observations could be explained by the release of $\mathrm{Ca}^{2+}$ and $\mathrm{Si}^{4+}$ from the NPs to the surrounding environment. ${ }^{123}$

Another approach is the incorporation of carbon nanotubes for the development of bone-like materials. Multiwalled carbon nanotubes (MWCNT) have shown to improve the compressive strength and elastic modulus of 45S5 Bioglass ${ }^{\circledR}$ scaffolds, ${ }^{4}$ tensile modulus, and strength of chitosan films ${ }^{5}$ and enhancement of surface roughness in carbon nanotubepoly(lactide-co-glycolide) composite scaffolds. ${ }^{124} \mathrm{~L}$. Chen et al. have demonstrated that MC3T3-E1 cell proliferation was significantly higher in chitosan - MWCNT/HAp nanocomposites when compared to chitosan/HAp scaffolds. ${ }^{125} \mathrm{~A}$ result that can be attributed to the capacity of MWCNT to adsorb proteins, thus affecting cell behavior. ${ }^{126}$ By its turn, the incorporation of single-walled carbon nanotubes (SWCNT) within a PLGA matrix, forming SWCNT/PLGA composites, also revealed superior properties. These include a higher cell proliferation rate of MC3T3-E1 cells and increased compressive modulus and ultimate compressive strength of SWCNT/PLGA composites, when compared to PLGA alone. ${ }^{127}$

As reviewed by Castro, ${ }^{128}$ magnetic NPs are also being applied for TE, including in the design of scaffolds for bone TE. These NPs are being used either to produce superparamagnetic responsive nanofibrous scaffolds ${ }^{129}$ or to improve cell adhesion, proliferation, and differentiation on ceramic scaffolds. ${ }^{130}$ The incorporation of silica $\mathrm{NPs}^{55}$ onto PCL fibers has been reported to increase its surface roughness and wettability. Moreover, such fibers revealed superior osteoconductivity and osteoinductivity, showing the potential for further uses in bone TE.

Recently, gold NPs have arisen a great interest as osteogenic agents, due to their potential to promote cell differentiation toward an osteogenic phenotype in vitro. ${ }^{131,132}$ This capacity may be related to the activation of ERK/MAPK 
pathway by AuNPs. ${ }^{131}$ The combination of gelatin scaffolds and these NPs has also promoted osteogenic differentiation of adipose-derived stem cells (ASCs) both in vitro and in vivo, in a dose-dependent manner. ${ }^{133}$

\section{NPs as carriers}

Adsorbing molecules of interest to a biomaterial surface can overcome problems associated with systemic delivery, such as rapid body clearance. ${ }^{134}$ Thus, nanomaterials can be used for in vitro drug and gene delivery, dispersed on culture medium, or can be incorporated into scaffolds to deliver and maintain the physiochemical cues needed during the regeneration process. Such bivalent systems are then able to support cells and also provide growth and differentiation factors. ${ }^{87}$ Studies using several types of NPs such as polymeric, ${ }^{135-143}$ liposomes, ${ }^{12,144-146}$ silica, ${ }^{147,148}$ and calcium phosphate ceramic NPs ${ }^{149-151}$ indicated that the use of nanoparticulate systems as carriers allow a sustained delivery of their cargo. Table 2 summarizes the outcomes of NPs used as drug and gene carriers.

Drug Delivery. Bone homeostasis is maintained by the balance between osteoblasts (bone-forming cells) and osteoclasts (bone-resorbing cells). ${ }^{152}$ Consequently, for a regenerative process, osteoblastic activity should be supported, leading to a superior bone deposition in favor of bone resorption. This can be achieved through growth factors delivery, namely, bone morphogenetic proteins (BMP), a member of transforming growth factor (TGF)- $\beta$ superfamily. ${ }^{134}$ These molecules stimulate the primary signal for osteogenic differentiation, from noncommitted pluripotent cells to mineral-depositing osteoblasts. ${ }^{138}$ There are more than 20 identified BMPs, but BMP-2 and BMP-7 are the ones most commonly used, and are already approved by FDA for clinical applications. ${ }^{153}$ As reviewed by Z. Haidar et al., ${ }^{154}$ there are several ways to deliver these growth factors. One possibility is to include BMP-2 within polymeric NPs, ${ }^{14,17,18,138,140}$ such as used by L. Cao et al. ${ }^{155}$ Photocross-linked hydrogel incorporating recombinant human BMP-2 loaded 2-N, 6-O-sulfated chitosan NPs showed good cell viability, adhesion, and time-dependent ingrowth when in culture with human mesenchymal stem cells (MSCs). Moreover, in vivo studies using a rabbit radius critical defect compared the outcomes of hydrogels containing BMP-2loaded chitosan NPs with hydrogels directly supplemented with BMP-2. The results have shown that the incorporation of BMP-2 within the NPs improved new bone replacement and induced the consolidation of the bone marrow cavity, after 12 weeks. ${ }^{155}$ Another approach was based on sequential growth factor delivery, to mimic the natural process of healing. Sequential BMP-2/BMP-7 delivery was achieved by encapsulating different growth factors in NPs constituted by polymers with different degradation rates, such as PLGA fast degradation rate - and poly(3-hydroxybutyrate-co-3hydroxyvalerate) (PHBV) - slow degradation rate. The combination of BMP-2-loaded PLGA nanocapsules and BMP-7loaded PHBV nanocapsules supported the sequential delivery of BMPs, that is, BMP-2 followed by BMP-7. Compared to simultaneous delivery of BMPs, this approach was found to enhance the differentiation of MSCs into osteoblasts in vitro, while decreasing the proliferation rate. ${ }^{139}$ Following this work, Yilgor et al. ${ }^{16}$ incorporated this dual-system inside chitosan-based scaffolds, creating a bifunctional construct, able to support cell growth and effectively deliver growth factors.

Another frequently used molecule in bone TE is dexamethasone (Dex), a glucocorticoid known to promote the osteogenic differentiation of marrow stromal cells. However, as a glucocorticoid, Dex may cause unwanted side effects in humans, such as secondary osteoporosis. ${ }^{156}$ To avoid these effects, Oliveira et al. designed a dexamethasone-loaded carboxymethylchitosan/poly(amidoamine) dendrimer NPs (Dexloaded CMCht/PAMAM). ${ }^{142}$ Rat bone marrow stromal cells were cultured in vitro, supplemented with the dendrimers and then seeded on HAp and starch-polycaprolactone (SPCL) scaffolds. Under these conditions, cells have positively differentiated into osteoblasts. Afterward, the group found that Dex-loaded CMCht/PAMAM dendrimers have a $\mathrm{pH}$ and ionic-responsive nature and are able to promote superior ectopic de novo bone formation, upon subcutaneous implantation on the back of rats for a period of 2 and 4 weeks. ${ }^{10,143}$ These works evidence the intracellular preprogramming potential and show how nanocarriers can be used to achieve this purpose, leading to the development of new bone tissue. Figure 7 shows the rationale of drug intracellular delivery promoting osteogenesis, starting in vitro and concluding in vivo. In a recent work, Hasani-Sadrabadi et al. ${ }^{157}$ optimized the production of chitosan NPs as vehicle for Dex delivery, using a microfluidic approach. By changing the mixing rate on the microfluidic device, the authors were able to control the size, surface charge, and cargo release rate from NPs, parameters that have affected the different osteogenic markers including osteoblast-related gene expression of MSCs, ALP activity, osteocalcin content, and calcium deposition (Figure 8). In fact, microfluidic-assisted prepared NPs were more effective than bulk synthetized NPs. Moreover, among the particles produced by microfluidics, smaller NPs were more prone to be internalized by MSCs, resulting in an improved differentiation profile, as compared with larger NPs sizes. ${ }^{157}$ El-Fiqi et al. ${ }^{15}$ took advantage of mesoporous bioactive glass NPs to incorporate Dex. Such NPs were then added to polycaprolactone/gelatin nanofibrous scaffolds, resulting in a multifunctional scaffold with sustained drug release for 1 month. Dex delivery together with the nanocomposite scaffold stimulated the osteogenic differentiation of stem cells derived from periodontal ligament and improved in vivo bone formation. ${ }^{15}$ More recently, $\mathrm{Li}$ et al. developed a scaffold with controlled delivery of dexamethasone (Dex) and BMP-2. ${ }^{18}$ While dexamethasone was included within the polymeric phase of the electrospun scaffold, BMP-2 was first incorporated into chitosan-stabilized bovine serum albumin (BSA) NPs, to maintain the bioactivity of the growth factor. The resulting polymeric nanofibers confer a multibarrier structure, delaying the BMP-2 delivery. Consequently, BMP-2 exhibited a gentle release pattern, without the initial burst release observed for Dex. When applied in vivo, in a rat calvarial defect model, the scaffold successfully promoted the defect repair. For the authors, such dual-delivery system confers an advantage, as Dex can promote earlier calcified bone formation, whereas BMP-2, which is released later, is favorable for long-term new bone formation. ${ }^{18}$ The synergistic effect achieved by the combined release of BMP-2 and Dex was also studied by Zhou et al. ${ }^{158}$ The authors have used mesoporous silica NPs as delivery vehicle, by covalent incorporation of BMP-2 peptide on the surface and Dex inside the NPs pores. In vivo studies in rat revealed the effective 
Table 2. Summary of Recent Works of Drug and Gene Delivery with NPs

\begin{tabular}{|c|c|c|c|c|c|}
\hline Application & Type of NP & Cargo & Model & Outcome & Ref. \\
\hline \multirow[t]{17}{*}{ Drug delivery } & $\begin{array}{l}\text { Albumin }+ \text { PEI-PEG } \\
\text { coating }\end{array}$ & BMP-2 & $\begin{array}{l}\text { In vitro-human } \mathrm{C} 2 \mathrm{C} 12 \\
\text { cells; in vivo-rat. }\end{array}$ & $\begin{array}{l}\text { Reduced cytotoxicity; effective ex vivo } \\
\text { bone formation. }\end{array}$ & 17 \\
\hline & Albumin & BMP-2 & $\begin{array}{l}\text { In vitro-rat bone mar- } \\
\text { row mesenchymal } \\
\text { stem cells; in vivo-rat } \\
\text { calvarial defect model. }\end{array}$ & $\begin{array}{l}\text { Gentle release pattern of BMP-2; } \\
\text { osteoinduction; higher in vivo bone } \\
\text { repair. }\end{array}$ & 18 \\
\hline & $\begin{array}{l}\text { Heparin-conjugated } \\
\text { PLGA }\end{array}$ & BMP-2 & $\begin{array}{l}\text { In vitro-human bone } \\
\text { marrow mesenchymal } \\
\text { stem cells. }\end{array}$ & $\begin{array}{l}\text { Sustained release; extended in vivo } \\
\text { bone formation. }\end{array}$ & 140 \\
\hline & $\begin{array}{l}\text { 2-N, 6-O-sulfated } \\
\text { chitosan nanoparticles }\end{array}$ & BMP-2 & $\begin{array}{l}\text { In vitro-HUVECs, } \\
\text { C2C12, human mesen- } \\
\text { chymal stem cells; in } \\
\text { vivo-critical size } \\
\text { defect of rabbit radius. }\end{array}$ & $\begin{array}{l}\text { Sustained release; increased healing } \\
\text { rate and better repair. }\end{array}$ & 13,155 \\
\hline & PLGA/PHBV & BMP-2/BMP-7 & $\begin{array}{l}\text { In vitro-rat bone mar- } \\
\text { row mesenchymal } \\
\text { stem cells }\end{array}$ & $\begin{array}{l}\text { Sequential release due to different } \\
\text { degradation rates; increased } \\
\text { differentiation. }\end{array}$ & 16,139 \\
\hline & Elastin-like & BMP-2 and BMP-14 & In vitro- $\mathrm{C} 2 \mathrm{C} 12$ cells & $\begin{array}{l}\text { Induction of ALP activity and } \\
\text { osteogenic mineralization; BMPs } \\
\text { activity preserved. }\end{array}$ & 14 \\
\hline & HAp & Osteopontin & $\begin{array}{l}\text { In vivo-canine endo- } \\
\text { sseous gap implant } \\
\text { model. }\end{array}$ & Enhanced new bone formation. & 151 \\
\hline & Chitosan & BMP-7 and bFGF & $\begin{array}{l}\text { In vitro-fetal } \\
\text { osteoblasts. }\end{array}$ & $\begin{array}{l}\text { Improved cell viability and } \\
\text { differentiation due to growth factor } \\
\text { sustained release. }\end{array}$ & 136 \\
\hline & Mesoporous silica & $\begin{array}{l}\text { BMP-2-derived peptide; } \\
\text { dexamethasone }\end{array}$ & $\begin{array}{l}\text { In vitro-bone mesen- } \\
\text { chymal stem cells; } \\
\text { in vivo-Sprague- } \\
\text { Dawley rats. }\end{array}$ & $\begin{array}{l}\text { Effective internalization of NPs; } \\
\text { successful and enhanced in vitro } \\
\text { differentiation; ectopic bone } \\
\text { formation. }\end{array}$ & 158 \\
\hline & Dendrimer & Dexamethasone & $\begin{array}{l}\text { In vitro-rat bone mar- } \\
\text { row stromal cells; in } \\
\text { vivo-Fischer } 344 / \mathrm{N} \\
\text { rats. }\end{array}$ & $\begin{array}{l}\text { Intracellular delivery of dexamethasone; } \\
\text { promote osteogenic differentiation; } \\
\text { promote de novo bone formation } \\
\text { in vivo. }\end{array}$ & 10,142 \\
\hline & Chitosan & Dexamethasone & $\begin{array}{l}\text { In vitro-rat mesenchy- } \\
\text { mal stem cells }\end{array}$ & $\begin{array}{l}\text { Fine-tuned production; smaller NPs } \\
\text { with better results due to higher } \\
\text { internalization }\end{array}$ & 157 \\
\hline & Bioactive Glass & Dexamethasone & $\begin{array}{l}\text { In vitro-rat periodontal } \\
\text { ligament stem cells; in } \\
\text { vivo-rat calvarial } \\
\text { defect model. }\end{array}$ & $\begin{array}{l}\text { Sustained drug release; improved bone } \\
\text { formation. }\end{array}$ & 15 \\
\hline & Gelatin-based micelles & Dexamethasone & $\begin{array}{l}\text { In vitro-rat bone mar- } \\
\text { row mesenchymal } \\
\text { stem cells; in vivo- } \\
\text { rat ulna defect. }\end{array}$ & $\begin{array}{l}\text { NPs } \mathrm{pH} \text {-responsive; enhanced in vitro } \\
\text { osteogenic differentiation and de } \\
\text { novo bone formation in vivo. }\end{array}$ & 33 \\
\hline & Liposomes & Dexamethasone & $\begin{array}{l}\text { In vitro-human bone } \\
\text { marrow-derived mes- } \\
\text { enchymal stem cells }\end{array}$ & Earlier osteogenic differentiation & 144 \\
\hline & Liposomes & EGF & In vivo-wistar rats & $\begin{array}{l}\text { Faster recovery from tooth extraction; } \\
\text { controlled delivery and protection of } \\
\text { drug. }\end{array}$ & 145 \\
\hline & Albumin & Resveratrol & $\begin{array}{l}\text { In vitro-human bone } \\
\text { marrow-derived mes- } \\
\text { enchymal stem cells }\end{array}$ & $\begin{array}{l}\text { Increased ALP activity and calcium } \\
\text { deposits on scaffolds with NPs. }\end{array}$ & 135 \\
\hline & $\begin{array}{l}\text { Chitosan-chondroitin } \\
\text { sulphate }\end{array}$ & Platelet lysate & In vitro-human ASCs & $\begin{array}{l}\text { Controlled release of platelet lysates } \\
\text { enhanced osteogenic differentiation. }\end{array}$ & 137 \\
\hline \multirow[t]{5}{*}{ Gene Delivery } & $\begin{array}{l}\text { Aminated } \\
\text { mesoporous silica }\end{array}$ & BMP-2 plasmid DNA & $\begin{array}{l}\text { In vitro-rat bone mar- } \\
\text { row mesenchymal } \\
\text { stem cells }\end{array}$ & $\begin{array}{l}\text { High transfection efficiency; successful } \\
\text { production of BMP-2 protein on } \\
\text { transfected cells. }\end{array}$ & 147 \\
\hline & Dendrimer & BMP-2 plasmid DNA & $\begin{array}{l}\text { In vitro-rat mesenchy- } \\
\text { mal stem cells }\end{array}$ & $\begin{array}{l}\text { Low transfection levels; successful pro- } \\
\text { motion of osteogenic differentiation. }\end{array}$ & 11 \\
\hline & Calcium phosphate & BMP-2 plasmid DNA & $\begin{array}{l}\text { In vitro-MC3T3-E1 } \\
\text { cells; }\end{array}$ & $\begin{array}{l}\text { High DNA incorporation; sustained } \\
\text { release; injectable system; successful } \\
\text { bony tissue formation. }\end{array}$ & 150 \\
\hline & Silver & $\operatorname{miR}-148 b$ & $\begin{array}{l}\text { In vitro-humanASCs; in } \\
\text { vivo-critical size } \\
\text { mouse calvarial defect. }\end{array}$ & $\begin{array}{l}\text { Temporal controlled release; spatial/ } \\
\text { temporal-controlled differentiation } \\
\text { upon light irradiation. }\end{array}$ & 163,164 \\
\hline & Calcium phosphate & $\begin{array}{l}\text { siRNA targeting } \\
\text { noggin }\end{array}$ & In vitro-mice ASCs & $\begin{array}{l}\text { NPs modified with glutamine- } \\
\text { conjugated oligochitosan are more } \\
\text { stable; effective suppression of NOG } \\
\text { protein with increased osteogenic } \\
\text { differentiation. }\end{array}$ & 89 \\
\hline
\end{tabular}

ALP, alkaline phosphatase; ASCs, adipose-derived stem cells; bFGF, basic fibroblast growth factor; BMP, bone morphogenetic protein; EGF, epidermal growth factor; HAp, hydroxyapatite; HUVECs, human umbilical vein endothelial cells; PEG, polyethylene glycol; PEI, polyethylenimine; PLGA, poly lactic-co-glycolic acid; PHBV, poly(3-hydroxybutyrate-co-3-hydroxyvalerate); siRNA, small interfering RNA. 


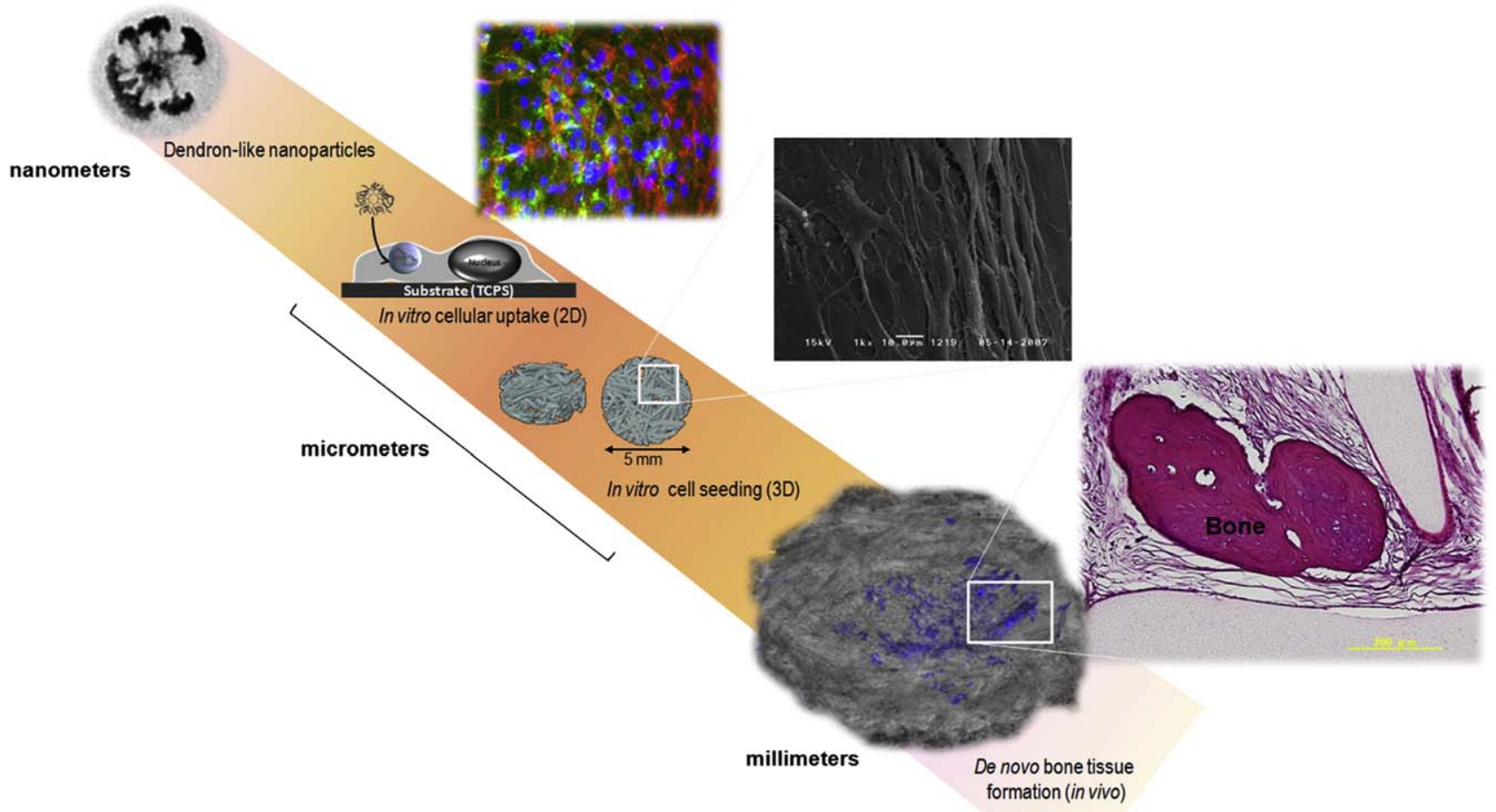

Figure 7. Schematic illustration of Oliveira et al. approach.

Dendron-like NPs are internalized by stem cells in vitro, and then cells are seeded onto SPCL scaffolds and implanted. Release of Dex to the cytoplasm will occur and de novo bone formation (blue areas) is observed within SPCL scaffolds after 4 weeks of implantation. Reprinted from Ref. 10 with permission from Elsevier.

A

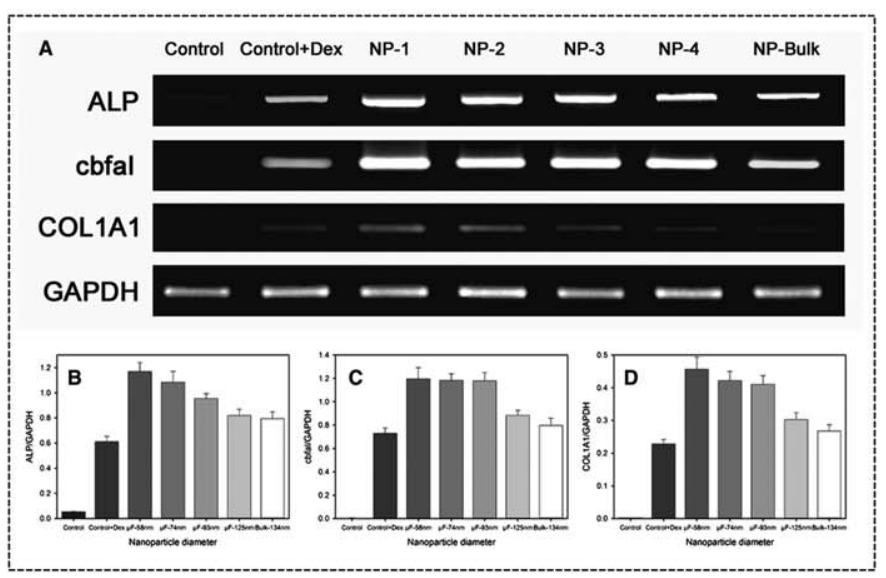

B
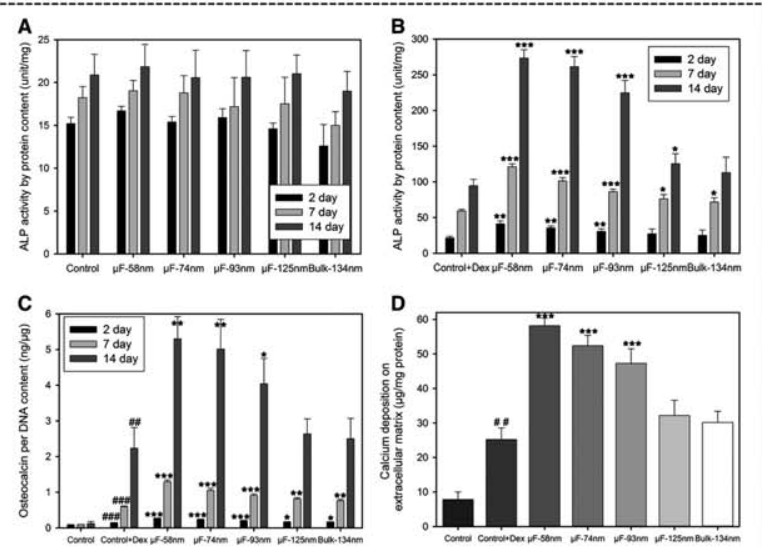

Figure 8. Effect of the microfluidics and bulk Dex-loaded chitosan NPs in mesenchymal stem cells (MSCs).

Panel A: Effect of the microfluidics and bulk Dex-loaded chitosan NPs on Alkaline phosphatase (ALP), core binding factor alpha 1 (cbfal), alpha I chain of collagen type I (COL1A1), and glyceraldehyde-3-phosphate dehydrogenase (GAPDH) gene expression in MSCs. Representative image of reverse transcription polymerase chain reaction (RT-PCR). MSCs were cultured in the absence and presence of NPs (A). The mRNA levels of ALP (B), cbfal (C), and COL1A1 (D) in cells, compared and normalized with mRNA of GAPDH in the same sample using RT-PCR. NP-1: MSCs treated with medium containing Dex-loaded microfluidic-obtained $58 \mathrm{~nm}$ NPs $(\mu \mathrm{F}-58 \mathrm{~nm})$. NP-2: MSCs treated with medium containing Dex-loaded $\mu$ F$74 \mathrm{~nm}$ NPs. NP-3: MSCs treated with medium containing Dex-loaded $\mu$ F-93 nm NPs. NP-4: MSCs treated with medium containing Dex-loaded $\mu$ F$125 \mathrm{~nm}$ NPs. NP-bulk: MSCs treated with medium containing Dex-loaded bulk NPs. Values indicate mean \pm SD; Panel B: ALP activity by protein content without (A) and with Dex (B). Osteocalcin per DNA content of MSCs after culturing in culture media containing microfluidics-assisted prepared NPs of different sizes for periods of 2, 7, and 14 days (C). Calcium content deposited on the extracellular matrix (D). The cells were transfected with Dex-containing chitosan microfluidics NPs and cultured for 21 days. Results are expressed as average \pm SD. Adapted and reprinted from Ref. 157 with kind permission from Elsevier.

osteoblast differentiation and bone regeneration after 3 weeks of intramuscular implantation. Liposomes were also reported as carriers for Dex intracellular delivery, promoting earlier osteogenic differentiation of human bone marrow
MSCs without cytotoxicity. ${ }^{144}$ Liposomes are also being used for the delivery of other components, such as antibacterial drugs that can be released within scaffolds to inhibit the growth of bacterial biofilms, ${ }^{159}$ and for epidermal growth 
factor (EGF) delivery on rat tooth sockets. In the latter case, the liposomes allowed a controlled release of EGF that stimulated MSCs migration and osteoblast differentiation. While free exogenous EGF in PBS was cleared faster and did not lead to full wound regeneration, EGF entrapped in liposomes allowed faster recovery, with approximately $50 \%$ more bone trabeculae present after 21 days. ${ }^{145}$

Extracellular matrix molecules can also be used for bone regeneration improvement. Osteopontin, a key player in the bone remodeling process, was used to functionalize HAp NPs that were further mixed with poly-L-D-lactic acid (PDLLA) to create an implant coating. ${ }^{151}$ When incorporated in a canine endosseous gap implant model, the implants with osteopontin led to an increase in new bone formation within the implant porosities $(15 \pm 8 \%$ vs. $30 \pm 7 \%) .{ }^{151}$

Other strategies for drug delivery have been developed and hold great promise for bone TE. Jiang T. et al. ${ }^{160}$ modified PLGA NPs with a poly aspartic acid peptide that specifically binds to HAp present in bone. Thence, these particles can specifically bind to mineralized tissues, such as bone, paving the way for bone targeted drug delivery systems. Recently, our group has used a natural polysaccharide, gellan gum, to improve gold nanoparticles' behavior under physiological conditions. ${ }^{70}$ Gold nanorods coated with a bilayer of polyelectrolytes followed by a shell of gellan gum have shown superior stability over a wide range of $\mathrm{pH}$ and ionic strength as compared to bare ones. Moreover, when in contact with preosteoblast cells (SaOS-2), these hybrid particles are internalized by cells, without compromising their viability. $^{70}$ The same effect was noticed when gold nanorods were added to a rabbit adipose stem cells (ASCs) culture, as depicted in Figure 9. Furthermore, these NPs led to an enhanced mineralization capacity of SaOS-2, showing their potential for application on the scope of intracellular drug delivery and bone TE.

Gene Delivery. Gene delivery is also a promising approach, due to the possibility of long-term expression and consequent longer therapeutic effect. It can be achieved using either viral or nonviral vehicles that serve to both transport and provide protection of the genetic material from degradation once internalized by cells. Although viral vectors have shown a high transduction rate, there are some concerns related to their toxicity and immunogenicity. ${ }^{161}$ Nonviral vectors are built to bind to the genetic material by electrostatic interactions, and are considered a much safer strategy, although less efficient as compared to viral counterparts. ${ }^{162}$ To be successful, the vehicles must be able to pass through the cellular membrane and to escape from the endocytic pathway. Then, nanoparticles arise as strategic tools for gene delivery mostly due to their size and simple functionalization.

T. Kim et al. ${ }^{147}$ and J. Santos et al. ${ }^{11}$ have developed systems to deliver BMP-2 DNA into rat MSCs. The first group used amine-modified mesoporous silica NPs to incorporate plasmid DNA encoding the growth factor. The functionalization with amine groups, together with the porous structure of NPs, improved the loading efficiency of the genetic material up to approximately $18 \%$. After transfection, $66 \%$ of transfected cells expressed BMP-2 protein. Moreover, the transfection procedure promoted osteogenic differentiation of MSCs after 14 days, with a significant increase in the expression of different bone related genes such as bone sialoprotein, osteopontin, and osteocalcin. ${ }^{147}$ When compared to nontransfected cells, the expression of these genes was

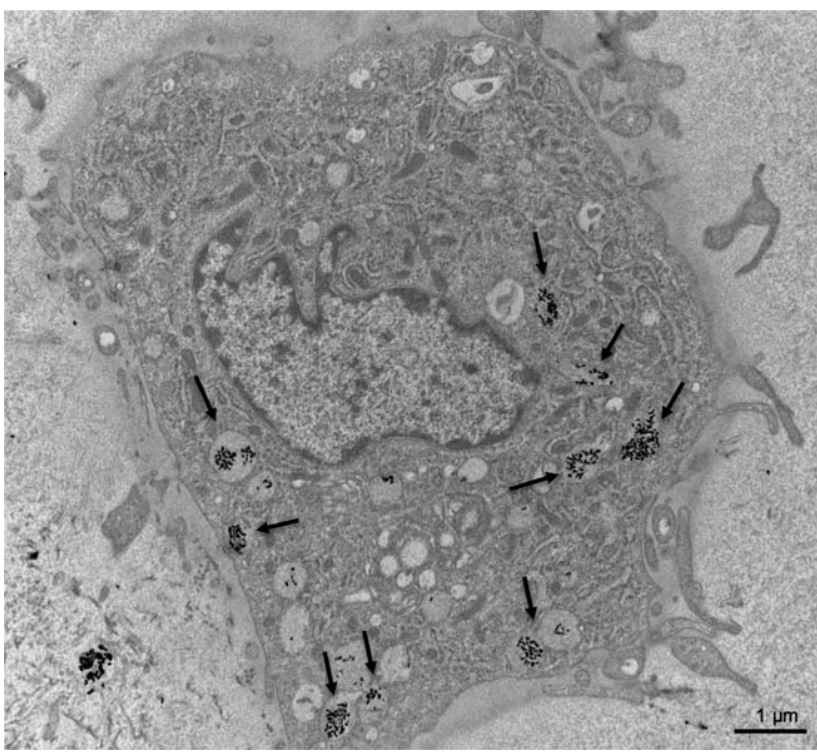

Figure 9. Transmission electron microscopy (TEM) images of rabbit ASCs culture in presence of gellan gumcoated gold nanorods.

Black arrows point to internalized NPs. Author personal collection.

approximately three times (bone sialoprotein) and five times (osteopontin and osteocalcin) higher. On the other hand, PAMAM dendrimers were used by J. Santos et al. ${ }^{11}$ Transfection of MSCs was shown to be dependent on dendrimer generation, the amine-to-phosphate group ratio, and the cell passage number. The process efficiency of human BMP-2 was very low, but it was still sufficient to promote the osteogenic differentiation of MSCs in vitro. ${ }^{11}$ A gene delivery system, composed of an injectable alginate hydrogel with calcium phosphate NPs loaded with BMP-2 encoding plasmid, was reported by Krebs et al. ${ }^{150}$ Such particles could release the plasmid DNA in a sustainable manner in vitro and were incorporated in an injectable alginate hydrogel, together with MC3T3-E1 pre-osteoblast cells. When injected subcutaneously in the back of mice, MC3T3-E1 cells present within the hydrogel could produce bony tissue after 2.5 weeks, showing the potential of this minimal invasive method.

Another approach involves the intracellular delivery of microRNAs (miRNA), small molecules that regulate posttranscriptional events, to control the osteogenic differentiation. Some miRNA, as miR-148b, have shown to be related to osteogenesis of MSCs. Bearing this in mind, Qureshi et al. ${ }^{163}$ designed a photoresponsive system that delivers miR-148b in a temporally controlled manner, to induce osteogenic differentiation in human adipose-derived stem cells (ASCs). ${ }^{163}$ The miR-148b was tethered to silver NPs via a photocleavable linker, which breaks when photoactivated by an external light source. The construct appears as inert until photoactivation occurs, where the miR-148b is released from particles. The application of this system allowed a spatial/temporal-controlled differentiation of human ASCs in vitro and in vivo. ${ }^{164}$

\section{Imaging}

Cell-based therapies, namely stem cell-based, are arising as a promising approach in regenerative medicine field, due to their inherent biological properties. ${ }^{165}$ However, there are a substantial number of questions regarding the outcomes of 


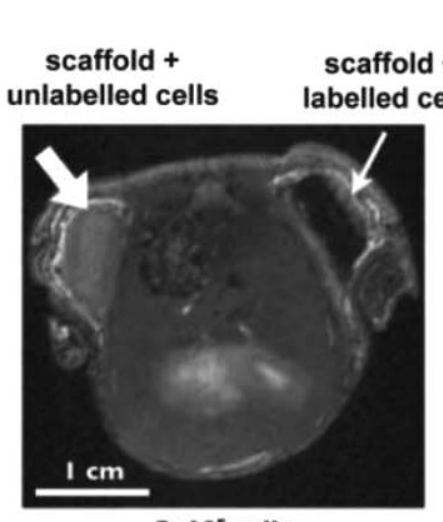

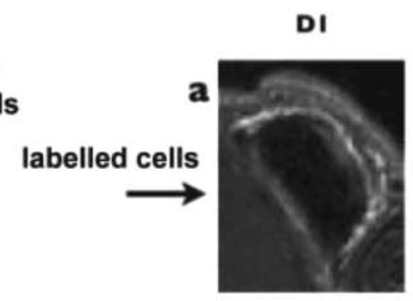

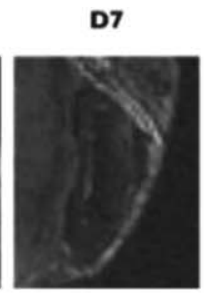

D14
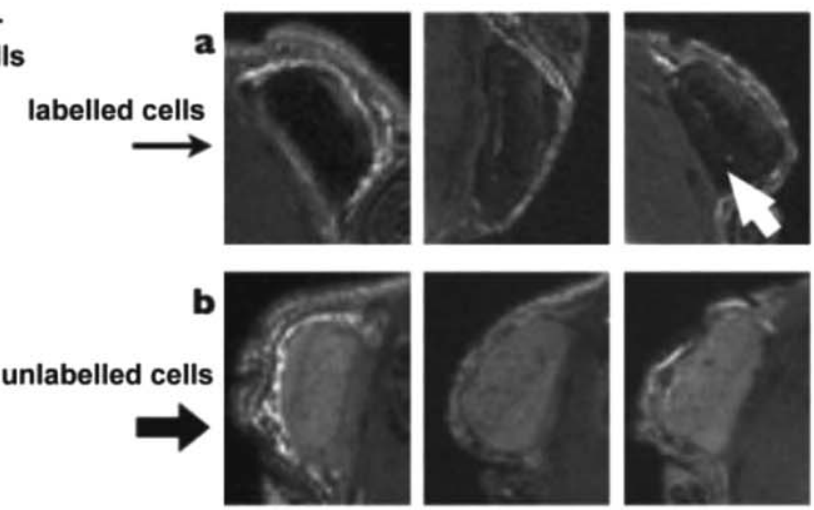

D21
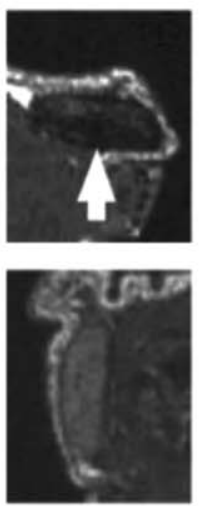

D28
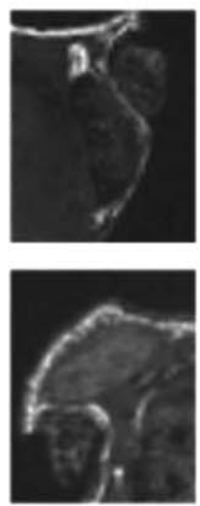

Figure 10. In vivo MRI of scaffolds seeded with labelled human adipose stem cells (ASCs)

In vivo MRI of scaffolds loaded with $5 \times 10^{5}$ labeled (a) or unlabeled human ASCs (b) per $20 \mathrm{~mm}^{3}$ disk at different times (days 1 , $7,14,21$, and 28) after implantation. On the left, macroscopic MRI images obtained at day 1 showing both scaffold loaded with labeled and unlabeled cells seeded with $5 \times 10^{5}$. The arrows indicate the position of the scaffold with labeled (small arrow on the right) and unlabeled cells (large arrow on the right). Images were obtained at $4.7 \mathrm{~T}$ with a $\mathrm{T} 2 *$-gradient echo sequence. Reprinted from Ref. 21 with kind permission from eCM journal (http://www.ecmjournal.org).
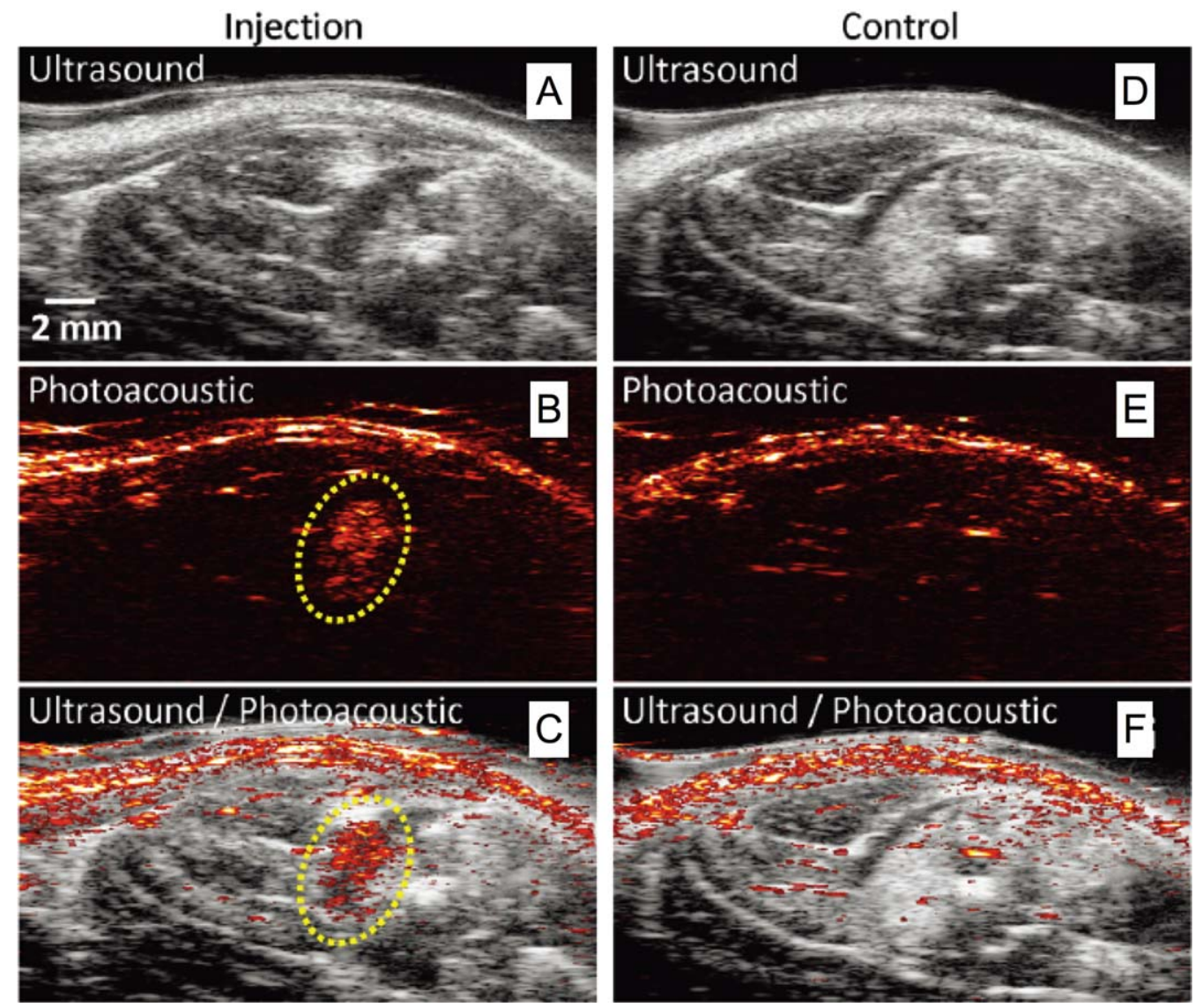

Figure 11. In vivo monitoring of MSCs labeled with gold NPs by ultrasound and photoacoustic (US/PA) imaging.

(A-C) In vivo ultrasound, photoacoustic, and US/PA images of a gel containing MSCs loaded with gold NPs injected in the lateral gastrocnemius of a Lewis rat $\left(1 \times 10^{5}\right.$ cells $\left./ \mathrm{mL}\right)$. Injection depth was about $5 \mathrm{~mm}$ under the skin. (D-F) Control at the region of the lateral gastrocnemius of the other hind limb without any injection. Photoacoustic images were acquired at the wavelength of $760 \mathrm{~nm}$ with a fluence of $11 \mathrm{~mJ} / \mathrm{cm}^{2}$. Adapted and reprinted from Ref. 23.

such treatments, including stem cells biodistribution after transplantation, and their migration pattern. The development and implementation of monitoring tools capable of tracking injected stem cells has paved the way for a fuller comprehension of transplanted cells' fate and their interactions with the surrounding environment. To achieve such monitoring systems, cells need to be labeled either by indirect or direct methods. ${ }^{166}$ The former implies a genetic modification, such that the cells produce an imaging marker after transplantation. The reporter gene can be expressed while cells are alive, without any loss of signal over time. Nevertheless, the difficulty of getting images of deep body structures, along with the impossibility of using genetically modified cells in clinics, hinders future applications in regenerative medicine. 
Table 3. Summary of Recent Works of Imaging Using NPs

\begin{tabular}{|c|c|c|c|c|c|c|}
\hline Application & Type of NP & Detection method & Concentration & Model & Outcome & Ref. \\
\hline \multirow[t]{8}{*}{ Imaging } & $\begin{array}{l}\text { Ultrasmall } \\
\text { SPIO }\end{array}$ & MRI & $15 \mathrm{mM}\left(\mathrm{Fe}^{3+}\right)$ & $\begin{array}{l}\text { In vitro-Human ASCs; } \\
\text { in vivo-Nude mice. }\end{array}$ & $\begin{array}{l}\text { Efficient internalization without } \\
\text { cytotoxicity; successful track- } \\
\text { ing after in vivo transplant. }\end{array}$ & 21 \\
\hline & SPIO & MRI & $\begin{array}{l}25,50, \text { and } \\
100 \mu \mathrm{g} / \mathrm{mL}\end{array}$ & $\begin{array}{l}\text { In vitro-ASCs and bone } \\
\text { marrow mesenchymal } \\
\text { stem cells }\end{array}$ & $\begin{array}{l}\text { Cell viability decreased with } \\
\text { higher concentrations; adipo- } \\
\text { genic and osteogenic differen- } \\
\text { tiation were hampered by the } \\
\text { presence of SPIO. }\end{array}$ & 172 \\
\hline & SPIO & MRI & $25 \mu \mathrm{g} / \mathrm{mL}$ & $\begin{array}{l}\text { In vitro- } \mathrm{Rat} / \mathrm{mice} \text { bone } \\
\text { marrow mesenchymal } \\
\text { stem cells } \\
\text { In vivo-C } 57 \mathrm{BL} / 6 \text { mice }\end{array}$ & $\begin{array}{l}\text { Successful observation by MRI; } \\
\text { particle uptake was higher in } \\
\text { presence of facilitating agents } \\
\text { (PLL and protamine); osteo- } \\
\text { genic, adipogenic and condro- } \\
\text { genic differentiation were not } \\
\text { affected. }\end{array}$ & 179 \\
\hline & Dendrimer-QDs & Fluorescence & $10 \mathrm{nM}$ & $\begin{array}{l}\text { In vitro-Mice } \\
\text { mesenchymal } \\
\text { stem cells; } \\
\text { in vivo-C57BL/6 mice. }\end{array}$ & $\begin{array}{l}\text { Conjugation of QDs with den- } \\
\text { drimers allowed endocytic } \\
\text { escape; longer fluorescent } \\
\text { emission both in vitro and in } \\
\text { vivo. }\end{array}$ & 22 \\
\hline & QDs & Fluorescence & $5 \mathrm{nM}$ & $\begin{array}{l}\text { In vivo-Nude rat critical } \\
\text { size defect }\end{array}$ & $\begin{array}{l}\text { Negative impact on in vivo per- } \\
\text { formance; retention of QDs in } \\
\text { macrophages. }\end{array}$ & 177 \\
\hline & AuNPs & $\begin{array}{l}\text { Ultrasound-guided } \\
\text { photoacoustic } \\
\text { imaging }\end{array}$ & $\begin{aligned} \approx & {[4.53 \pm 0.04] \times } \\
& 10^{5} \mathrm{NPs} / \mathrm{cell}\end{aligned}$ & $\begin{array}{l}\text { In vitro-Mesenchymal } \\
\text { stem cells; } \\
\text { in vivo-Lewis rat. }\end{array}$ & $\begin{array}{l}\text { High detection sensitivity; high } \\
\text { temporal and spatial } \\
\text { resolution. }\end{array}$ & 23 \\
\hline & AuNPs & $\begin{array}{l}\text { Two-photon } \\
\text { microscopy and } \\
\text { photoacoustic } \\
\text { microscopy }\end{array}$ & $25 \mathrm{pM}$ & $\begin{array}{l}\text { In vitro-Human } \\
\text { mesenchymal stem cells; } \\
\text { in vivo-Nude mice }\end{array}$ & $\begin{array}{l}\text { Successful labeling and tracking } \\
\text { of cells; long-term imaging; } \\
\text { increased depth resolution. }\end{array}$ & 66 \\
\hline & $\begin{array}{l}\text { Mesoporous } \\
\text { silica doped } \\
\text { with } \mathrm{Gd}^{3+}\end{array}$ & MRI & $50 \mu \mathrm{g} / \mathrm{mL}$ & $\begin{array}{l}\text { In vitro-rat mesenchymal } \\
\text { stem cells; } \\
\text { in vivo-Sprague } \\
\text { Dawley rat. }\end{array}$ & $\begin{array}{l}\text { Long-term imaging; high } \mathrm{Gd}^{3+} \\
\text { payload. }\end{array}$ & 176 \\
\hline
\end{tabular}

ASCs, adipose-derived stem cells; AuNPs, gold nanoparticles; MRI, magnetic resonance imaging; PLL, poly-L-lysine; QDs, quantum dots; siRNA, small interfering RNA; SPIO, superparamagnetic iron oxide.

Direct methods employ a previous ex vivo incubation with contrast agents, which are internalized by cells, before the transplant. This approach allows the application of different imaging techniques, overcoming some flaws of indirect methods. However, it implies a decrease of marker concentration over time. ${ }^{166}$

Considering the direct methods, NPs appear as a good alternative method for noninvasive cell monitoring and tracking. As contrast agents, NPs can be detected by several imaging modalities, including magnetic resonance (MRI), ${ }^{118,167}$ computed tomography (CT), ${ }^{168}$ and photoacoustic imaging. ${ }^{169}$ Some products are, in fact, already on market for this purpose, as reviewed by Wang et al. ${ }^{19}$

From a regenerative perspective, MSCs are an important cell population due to their capacity to differentiate into distinct lineages, including the osteogenic lineage. ${ }^{170}$ Therefore, MSCs labeling has become an important tool, allowing their post-transplantation tracking, which is essential to understand their in vivo behavior, biodistribution, and molecular regulation. $^{20}$ The most used NPs are SPIONs, ${ }^{21,171-174}$ gold NPs, ${ }^{74,175}$ mesoporous silica NPs, ${ }^{176}$ and QDs. ${ }^{22,177}$

SPIONs were found to be efficiently internalized by human MSCs, acting as a negative contrast for MRI scanning, as shown in Figure $10 .^{21}$ Although the labeling capacity is consistent across different studies, the effect on differentiation capacity is still a controversy point, highly dependent on the applied coating and concentration used. While some studies report impairment of osteogenic and chondrogenic differentiation ability, ${ }^{171,178}$ others did not find an impact of SPIONs labeling on the differentiation capacity of labeled cells. ${ }^{179}$ Recently, J. Fan et al. ${ }^{172}$ performed a comparative study between the labeling capacity on adiposederived MSCs and bone-derived MSCs. Results have shown that increasing concentrations of SPIONs led to a decrease in cell viability in both cell groups, as well as adipogenic and osteogenic differentiation potentials.

Studies with gold NPs have shown that these particles do not hinder the differentiation capacity of human MSCs. Zhang et al., ${ }^{66}$ and Tsai et al. ${ }^{180}$ reported no influence in the differentiation capacity of human MSCs and MG63osteoblast like cells, respectively. More recently, some authors reported that gold NPs were able to stimulate differentiation and mineralization of primary osteoblasts. ${ }^{70,131}$ After being labeled with these NPs, samples can be analyzed by photoacoustic tomography (Figure 11), allowing a deeper and higher detection sensitivity, compared to other methods such as MRI and fluorescence microscopy. ${ }^{23,66}$ Similarly, silica NPs have shown great potential as tracking agent. As an example, the work of Shen et al. ${ }^{176}$ took advantage of the mesoporous structure of silica NPs to incorporate gadolinium for further MRI detection. The preliminary in vitro studies revealed that gadolinium-silica NPs were successfully taken up by cells, without affecting cell viability and differentiation potential of both bone MSCs and neural stem cells. In vivo studies using rats demonstrated the feasibility of using gadolinium-silica NPs as long-term MRI probes.

It is noteworthy that imaging of bone-targeted MSCs is subject to some technical problems, mostly due to high mineralization in bone tissue, that hinder the follow-up of MSCs. Additionally, there is also a concern regarding the 
uncertain fate of NPs once inside the body. The label can be freed from cells by means of exocytosis and/or apoptosis, and then internalized by other cell types, which can lead to misconception of the imaging results. ${ }^{74,166}$ Research is still ongoing trying to improve the image acquisition process, thus allowing the wide use of these techniques in research and in the clinic. Table 3 condenses the most relevant works reported to date in this field.

\section{Final Remarks and Future Trends}

The incorporation of nanotechnology in TE applications has been providing a wide range of new opportunities for researchers and a new hope for future clinical applications. It is now possible to create structures not only within the same size range as natural occurring ones but also specifically tailored to fit with them. This specificity results from the possibility to modify NPs properties and functionalize them accordingly to the desired interaction. For bone TE, research has been done mostly in three areas showing promising results: scaffolds improvement, nanocarriers, and cell labeling for imaging. The conjugation of these three strategies in a single system might be the trend in this field. With this approach, it is possible not only to provide the appropriate scaffold and stimulate cell differentiation and maintenance through intracellular drug release, but also to track delivered cells in vivo. This labeling capacity has a great impact on the development of new solutions, since it enables the monitoring of cell biodistribution and function after transplantation for an extended time. Moreover, this labeling capacity can be used to understand how NPs distribute inside cells and how they interact with cytoplasmic elements, which is also extremely important to understand and improve NPs usage.

Despite the increase of NPs applications in research, it is still necessary to fully understand the interaction mechanisms between NPs and living organisms. Because of their small dimensions, the material properties are changed and chemical reactivity is highly increased. This means that size- and dose-dependent mechanistic paradigms of bulk materials are inaccurate when applied to NPs. Most of the reviewed works have included cytotoxicologic studies; however, that is insufficient to understand the real toxicological effect of NPs. Hence, Nanotoxicology is an area that needs to grow along with nanotechnology, providing safety profiles for each type of NPs. These studies should include a comprehensive characterization of NPs, regarding their size, material, shape, charge, and application mode (immobilized in scaffolds or free); estimated number of NPs used; pharmacokinetic studies, that is, how NPs are adsorbed, distributed, metabolized, and excreted by organisms; and NPs uptake dynamics and pathways. The establishment of representative models for each type of nanoparticle and toxicity test protocols, to standardize the collected data, is also needed.

Another key parameter that should be considered when designing NPs is the bench to market transition. This is a big challenge for researchers and engineers, as it implies a scale-up of laboratory procedures for an industrial scale, with an affordable cost. Additionally, all the procedures, from synthesis to shipping and storage, must be consistent with Good Manufacturing Practice (GMP), which is not always easy to accomplish.
Summing up, nanotechnology holds a great potential for bone TERM and can be used as multifunctional tool within different fields. Although we are getting closer to developing therapeutic approaches with clinical applications, there is still a substantial amount of investigation to do and challenges to surpass before this goal can be achieved.

\section{Acknowledgments}

This study was funded by QREN (ON.2 - NORTE-010124-FEDER-000018), as well as the European Union's FP7 Programme under grant agreement number REGPOTCT2012-316331-POLARIS. Sílvia Vieira was awarded an FCT PhD scholarship (SFRH/BD/102710/2014). The FCT distinction attributed to J.M.O. under the Investigator FCT program (IF/00423/2012 and IF/01285/2015) is also greatly acknowledged.

\section{Conflict of Interest}

The authors declare no conflict of interest.

\section{Literature Cited}

1. Langer R, Vacanti JP. Tissue engineering. Science. 1993; 260: 920-926.

2. Roohani-Esfahani S-I, Nouri-Khorasani S, Lu Z, Appleyard R, Zreiqat $\mathrm{H}$. The influence hydroxyapatite nanoparticle shape and size on the properties of biphasic calcium phosphate scaffolds coated with hydroxyapatite-PCL composites. Biomaterials. 2010; 31:5498-5509.

3. Kim H, Che L, Ha Y, Ryu W. Mechanically-reinforced electrospun composite silk fibroin nanofibers containing hydroxyapatite nanoparticles. Mater Sci Eng C Mater Biol Appl. 2014;40:324335.

4. Touri R, Moztarzadeh F, Sadeghian Z, Bizari D, Tahriri M, Mozafari M. The use of carbon nanotubes to reinforce 45S5 bioglass-based scaffolds for tissue engineering applications. Biomed Res Int. 2013;2013:8.

5. Aryaei A, Jayatissa AH, Jayasuriya AC. Mechanical and biological properties of chitosan/carbon nanotube nanocomposite films. J Biomed Mater Res A. 2014;102:2704-2712.

6. Laschke MW, Strohe a, Menger MD, Alini M, Eglin D. In vitro and in vivo evaluation of a novel nanosize hydroxyapatite particles/poly(ester-urethane) composite scaffold for bone tissue engineering. Acta Biomater. 2010;6:2020-2027.

7. Boissard CIR, Bourban P-E, Tami AE, Alini M, Eglin D. Nanohydroxyapatite/poly(ester urethane) scaffold for bone tissue engineering. Acta Biomater. 2009;5:3316-3327.

8. Qian J, Xu W, Yong X, Jin X, Zhang W. Fabrication and in vitro biocompatibility of biomorphic PLGA/nHA composite scaffolds for bone tissue engineering. Mater Sci Eng C Mater Biol Appl. 2014;36:95-101.

9. Chae T, Yang H, Leung V, Ko F, Troczynski T. Novel biomimetic hydroxyapatite/alginate nanocomposite fibrous scaffolds for bone tissue regeneration. J Mater Sci Mater Med. 2013;24: $1885-1894$.

10. Oliveira JM, Sousa RA, Malafaya PB, Silva SS, Kotobuki N, Hirose M, Ohgushi H, Mano JF, Reis RL. In vivo study of dendronlike nanoparticles for stem cells "tune-up": from nano to tissues. Nanomed Nanotechnol Biol Med. 2011;7:914-924.

11. Santos JL, Oramas E, Pêgo AP, Granja PL, Tomás H. Osteogenic differentiation of mesenchymal stem cells using PAMAM dendrimers as gene delivery vectors. J Control Release. 2009; 134:141-148.

12. Wang G, Mostafa NZ, Incani V, Kucharski C, Uludag H. Bisphosphonate-decorated lipid nanoparticles designed as drug carriers for bone diseases. J Biomed Mater Res A. 2012;100A:684693. 
13. Cao L, Wang J, Hou J, Xing W, Liu C. Vascularization and bone regeneration in a critical sized defect using 2-N,6-Osulfated chitosan nanoparticles incorporating BMP-2. Biomaterials. 2014;35:684-698.

14. Bessa PC, Machado R, Nürnberger S, Dopler D, Banerjee A, Cunha AM, Rodríguez-Cabello JC, Redl H, van Griensven M, Reis RL, Casal M. Thermoresponsive self-assembled elastinbased nanoparticles for delivery of BMPs. J Control Release. 2010;142:312-318.

15. El-Fiqi A, Kim J-H, Kim H-W. Osteoinductive fibrous scaffolds of biopolymer/mesoporous bioactive glass nanocarriers with excellent bioactivity and long-term delivery of osteogenic drug. ACS Appl Mater Interfaces. 2015; doi:10.1021/am5077759.

16. Yilgor P, Tuzlakoglu K, Reis RL, Hasirci N, Hasirci V. Incorporation of a sequential BMP-2/BMP-7 delivery system into chitosan-based scaffolds for bone tissue engineering. Biomaterials. 2009;30:3551-3559.

17. Zhang S, Kucharski C, Doschak MR, Sebald W, Uludag H. Polyethylenimine-PEG coated albumin nanoparticles for BMP-2 delivery. Biomaterials. 2010;31:952-963.

18. Li L, Zhou G, Wang Y, Yang G, Ding S, Zhou S. Controlled dual delivery of BMP-2 and dexamethasone by nanoparticleembedded electrospun nanofibers for the efficient repair of critical-sized rat calvarial defect. Biomaterials. 2014;37C:218229.

19. Wang Y, Xu C, Ow H. Commercial nanoparticles for stem cell labeling and tracking. Theranostics. 2013;3:544-560.

20. Hachani R, Lowdell M, Birchall M, Thanh NTK. Tracking stem cells in tissue-engineered organs using magnetic nanoparticles. Nanoscale. 2013; doi:10.1039/c3nr03861k.

21. Lalande C, Miraux S, Derkaoui SM, Mornet S, Bareille R, Fricain JC, Franconi JM, Le Visage C, Letourneur D, Amédée $\mathrm{J}$, Bouzier-Sore K. Magnetic resonance imaging tracking of human adipose derived stromal cells within three-dimensional scaffolds for bone tissue engineering. Eur Cell Mater. 2011;21: 341-354. Available at: http://www.ncbi.nlm.nih.gov/pubmed/ 21484704.

22. Higuchi Y, Wu C, Chang K-L, Irie K, Kawakami S, Yamashita F, Hashida M. Polyamidoamine dendrimer-conjugated quantum dots for efficient labeling of primary cultured mesenchymal stem cells. Biomaterials. 2011;32:6676-6682.

23. Nam SY, Ricles LM, Suggs LJ, Emelianov SY. In vivo ultrasound and photoacoustic monitoring of mesenchymal stem cells labeled with gold nanotracers. PLoS One. 2012;7:e37267.

24. Nicolas J, Mura S, Brambilla D, Mackiewicz N, Couvreur P. Design, functionalization strategies and biomedical applications of targeted biodegradable/biocompatible polymer-based nanocarriers for drug delivery. Chem Soc Rev. 2013;42:1147-1235.

25. Bangham AD. Surrogate cells or Trojan horses. The discovery of liposomes. Bioessays. 1995;17:1081-1088.

26. Allen TM, Cullis PR. Liposomal drug delivery systems: from concept to clinical applications. Adv Drug Deliv Rev. 2013;65: $36-48$.

27. Bozzuto G, Molinari A. Liposomes as nanomedical devices. Int J Nanomed. 2015;975:doi:10.2147/IJN.S68861.

28. Immordino ML, Dosio F, Cattel L. Stealth liposomes: review of the basic science, rationale, and clinical applications, existing and potential. Int J Nanomed. 2006;1:297-315.

29. Swaminathan J, Ehrhardt C. Liposomes for pulmonary drug delivery. In: Smyth HDC, Hickey AJ, eds. Controlled Pulmonary Drug Delivery SE - 14. Advances in Delivery Science and Technology. New York: Springer; 2011:313-334.

30. Gulati M, Grover M, Singh S, Singh M. Lipophilic drug derivatives in liposomes. Int J Pharm. 1998;165:129-168.

31. Al-Jamal WT, Kostarelos K. Liposomes: from a clinically established drug delivery system to a nanoparticle platform for theranostic nanomedicine. Acc Chem Res. 2011;44:1094-1104.

32. Torchilin VP. Recent advances with liposomes as pharmaceutical carriers. Nat Rev Drug Discov. 2005;4:145-160.

33. Santo VE, Ratanavaraporn J, Sato K, Gomes ME, Mano JF, Reis RL, Tabata Y. Cell engineering by the internalization of bioinstructive micelles for enhanced bone regeneration. Nanomedicine. 2015;10:1707-1721.
34. Yoo HS, Kim TG, Park TG. Surface-functionalized electrospun nanofibers for tissue engineering and drug delivery. Adv Drug Deliv Rev. 2009;61:1033-1042.

35. Rao JP, Geckeler KE. Polymer nanoparticles: Preparation techniques and size-control parameters. Prog Polym Sci. 2011;36: 887-913.

36. Hu X, Liu S. Recent advances towards the fabrication and biomedical applications of responsive polymeric assemblies and nanoparticle hybrid superstructures. Dalt Trans. 2015;44:39043922.

37. Hu X, Liu G, Li Y, Wang X, Liu S. Cell-penetrating hyperbranched polyprodrug amphiphiles for synergistic reductive milieu-triggered drug release and enhanced magnetic resonance signals. J Am Chem Soc. 2015;137:362-368.

38. Hu X, Hu J, Tian J, Ge Z, Zhang G, Luo K, Liu S. Polyprodrug amphiphiles: hierarchical assemblies for shape-regulated cellular internalization, trafficking, and drug delivery. J Am Chem Soc. 2013;135:17617-17629.

39. Langer K, Anhorn MG, Steinhauser I, Dreis S, Celebi D, Schrickel N, Faust S, Vogel V. Human serum albumin (HSA) nanoparticles: Reproducibility of preparation process and kinetics of enzymatic degradation. Int J Pharm. 2008;347:109-117.

40. Fàbregas A, Miñarro M, García-Montoya E, Pérez-Lozano P, Carrillo C, Sarrate R, Sánchez N, Ticó JR, Suñé-Negre JM. Impact of physical parameters on particle size and reaction yield when using the ionic gelation method to obtain cationic polymeric chitosan-tripolyphosphate nanoparticles. Int $J$ Pharm. 2013;446:199-204.

41. Vaculikova E, Grunwaldova V, Kral V, Dohnal J, Jampilek J. Preparation of candesartan and atorvastatin nanoparticles by solvent evaporation. Molecules. 2012;17:13221-13234.

42. Chung JW, Lee K, Neikirk C, Nelson CM, Priestley RD. Photoresponsive coumarin-stabilized polymeric nanoparticles as a detectable drug carrier. Small. 2012;8:1693-1700.

43. Thamake SI, Raut SL, Gryczynski Z, Ranjan AP, Vishwanatha JK. Alendronate coated poly-lactic-co-glycolic acid (PLGA) nanoparticles for active targeting of metastatic breast cancer. Biomaterials. 2012;33:7164-7173.

44. Verderio P, Bonetti P, Colombo M, Pandolfi L, Prosperi D. Intracellular drug release from curcumin-loaded PLGA nanoparticles induces G2/M block in breast cancer cells. Biomacromolecules. 2013;14:672-682.

45. Hans ML, Lowman AM. Biodegradable nanoparticles for drug delivery and targeting. Curr Opin Solid State Mater Sci. 2002;6: 319-327.

46. Buhleier E, Wehner W, Vögtle F. "Cascade"- and "nonskidchain-like" syntheses of molecular cavity topologies. Synthesis. 1978;1978:155-158.

47. Tomalia DA, Baker H, Dewald J, Hall M, Kallos G, Martin S, Roeck J, Ryder J, Smith P. A new class of polymers: Starburstdendritic macromolecules. Polym J. 1985;17:117-132.

48. Menjoge AR, Kannan RM, Tomalia DA. Dendrimer-based drug and imaging conjugates: design considerations for nanomedical applications. Drug Discov Today. 2010;15:171-185.

49. Tomalia DA. Birth of a new macromolecular architecture: dendrimers as quantized building blocks for nanoscale synthetic polymer chemistry. Prog Polym Sci. 2005;30:294-324.

50. Kojima C. Design of stimuli-responsive dendrimers. Exp Opin Drug Deliv. 2010;7:307-319.

51. Gillies ER, Fréchet JMJ. Dendrimers and dendritic polymers in drug delivery. Drug Discov Today. 2005;10:35-43.

52. Milhem OM, Myles C, McKeown NB, Attwood D, D'Emanuele A. Polyamidoamine Starburst dendrimers as solubility enhancers. Int $J$ Pharm. 2000;197:239-241.

53. Mecke A, Majoros IJ, Patri AK, Baker JR, Holl MMB, Orr BG. Lipid bilayer disruption by polycationic polymers: the roles of size and chemical functional group. Langmuir. 2005;21:10348-10354.

54. Slowing II, Vivero-Escoto JL, Wu C-W, Lin VS-Y. Mesoporous silica nanoparticles as controlled release drug delivery and gene transfection carriers. Adv Drug Deliv Rev. 2008;60:1278-1288.

55. Tang Y, Zhao Y, Wang X, Lin T. Layer-by-layer assembly of silica nanoparticles on 3D fibrous scaffolds: Enhancement of osteoblast cell adhesion, proliferation, and differentiation. J Biomed Mater Res A. 2013; 1-10. 
56. Wu X, Wu M, Zhao JX. Recent development of silica nanoparticles as delivery vectors for cancer imaging and therapy. Nanomed Nanotechnol Biol Med. 2014;10:297-312.

57. Lipski AM, Pino CJ, Haselton FR, Chen I-W, Shastri VP. The effect of silica nanoparticle-modified surfaces on cell morphology, cytoskeletal organization and function. Biomaterials. 2008; 29:3836-3846.

58. Lee JM, Kim B-S, Lee H, Im G-I. In vivo tracking of mesechymal stem cells using fluorescent nanoparticles in an osteochondral repair model. Mol Ther. 2012;20:1434-1442.

59. Bagwe RP, Yang C, Hilliard LR, Tan W. Optimization of dyedoped silica nanoparticles prepared using a reverse microemulsion method. Langmuir. 2004;20:8336-8342.

60. Yang K-N, Zhang C-Q, Wang W, Wang PC, Zhou J-P, Liang X-J. $\mathrm{pH}$-responsive mesoporous silica nanoparticles employed in controlled drug delivery systems for cancer treatment. Cancer Biol Med. 2014;11:34-43.

61. Han Y, Ying JY. Generalized fluorocarbon-surfactant-mediated synthesis of nanoparticles with various mesoporous structures. Angew Chemie Int Ed. 2005;44:288-292.

62. Gu J, Fan W, Shimojima A, Okubo T. Organic-inorganic mesoporous nanocarriers integrated with biogenic ligands. Small. 2007;3:1740-1744.

63. Möller K, Kobler J, Bein T. Colloidal suspensions of nanometer-sized mesoporous silica. Adv Funct Mater. 2007;17: 605-612.

64. Zhao PX, Li N, Astruc D. State of the art in gold nanoparticle synthesis. Coord Chem Rev. 2013;257:638-665.

65. Vial S, Nykypanchuk D, Yager KG, Tkachenko AV, Gang O. Linear mesostructures in DNA-nanorod self-assembly. ACS Nano. 2013;

66. Zhang YS, Wang Y, Wang L, Wang Y, Cai X, Zhang C, Wang LVXY. Labeling human mesenchymal stem cells with gold nanocages for in vitro and in vivo tracking by two-photon microscopy and photoacoustic microscopy. Theranostics. 2013;3:532-543.

67. Guo R, Zhang L, Qian H, Li R, Jiang X, Liu B. Multifunctional nanocarriers for cell imaging, drug delivery, and near-IR photothermal therapy. Langmuir. 2010;26:5428-5434.

68. Yeh Y-C, Creran B, Rotello VM. Gold nanoparticles: Preparation, properties, and applications in bionanotechnology. Nanoscale. 2012;4:1871-1880.

69. Huang X, Qian W, El-Sayed IH, El-Sayed MA. The potential use of the enhanced nonlinear properties of gold nanospheres in photothermal cancer therapy. Lasers Surg Med. 2007;39:747753.

70. Vieira S, Vial S, Maia FR, Carvalho M, Reis RL, Granja PL, Oliveira JM. Gellan gum-coated gold nanorods: an intracellular nanosystem for bone tissue engineering. RSC $A d v$. 2015;5: 77996-78005.

71. Yuan H, Khoury CG, Wilson CM, Grant GA, Bennett AJ, VoDinh T. In vivo particle tracking and photothermal ablation using plasmon-resonant gold nanostars. Nanomedicine. 2012;8: 1355-1363. Available at: http://linkinghub.elsevier.com/retrieve/ pii/S1549963412000238? showall = true.

72. Khlebtsov N, Bogatyrev V, Dykman L, Khlebtsov B, Staroverov S, Shirokov A, Matora L, Khanadeev V, Pylaev T, Tsyganova N, Terentyuk G. Analytical and theranostic applications of gold nanoparticles and multifunctional nanocomposites. Theranostics. 2013:3:167-180.

73. Vigderman L, Khanal BP, Zubarev ER. Functional gold nanorods: synthesis, self-assembly, and sensing applications. Adv Mater. 2012;24:4811-4841, 5014.

74. Meir R, Motiei M, Popovtzer R. Gold nanoparticles for in vivo cell tracking. Nanomedicine. 2014;9:2059-2069.

75. Murphy CJ, Gole AM, Stone JW, Sisco PN, Alkilany AM, Goldsmith EC, Baxter SC. Gold nanoparticles in biology: beyond toxicity to cellular imaging. Acc Chem Res. 2008;41: 1721-1730.

76. Colombo M, Carregal-Romero S, Casula MF, Gutiérrez L, Morales MP, Böhm IB, Heverhagen JT, Prosperi D, Parak WJ. Biological applications of magnetic nanoparticles. Chem Soc Rev. 2012;41:4306.

77. Sensenig R, Sapir Y, MacDonald C, Cohen S, Polyak B. Magnetic nanoparticle-based approaches to locally target therapy and enhance tissue regeneration in vivo. Nanomedicine. 2012;7: $1425-1442$.

78. Sun C, Lee JSH, Zhang M. Magnetic nanoparticles in MR imaging and drug delivery. Adv Drug Deliv Rev. 2008;60:12521265.

79. Yin H, Too HP, Chow GM. The effects of particle size and surface coating on the cytotoxicity of nickel ferrite. Biomaterials. 2005;26:5818-5826.

80. Villanueva A, Cañete M, Roca AG, Calero M, VeintemillasVerdaguer S, Serna CJ, Morales MP, Miranda R. The influence of surface functionalization on the enhanced internalization of magnetic nanoparticles in cancer cells. Nanotechnology. 2009; 20:115103.

81. Tanaka Y, Yamashita K. Fabrication processes for bioceramics. In: Kokubo TBT-B and their CA, ed. Woodhead Publishing Series in Biomaterials. Woodhead Publishing; 2008:28-52.

82. Yan L-P, Silva-Correia J, Correia C, Caridade SG, Fernandes EM, Sousa RA, Mano JF, Oliveira JM, Oliveira AL, Reis RL. Bioactive macro/micro porous silk fibroin/nano-sized calcium phosphate scaffolds with potential for bone-tissue-engineering applications. Nanomedicine. 2012;8:359-378.

83. Gaharwar AK, Dammu SA, Canter JM, Wu C-J, Schmidt G. Highly extensible, tough, and elastomeric nanocomposite hydrogels from poly(ethylene glycol) and hydroxyapatite nanoparticles. Biomacromolecules. 2011;12:1641-1650.

84. Chatterjee K, Sun L, Chow LC, Young MF, Simon CG. Combinatorial screening of osteoblast response to 3D calcium phosphate/ poly ( $\varepsilon$-caprolactone) scaffolds using gradients and arrays. Biomaterials. 2011;32:1361-1369.

85. Pina S, Oliveira JM, Reis RL. Natural-based nanocomposites for bone tissue engineering and regenerative medicine: a review. Adv Mater. 2015;27:1143-1169.

86. Wang P, Zhao L, Liu J, Weir MD, Zhou X, Xu HHK. Bone tissue engineering via nanostructured calcium phosphate biomaterials and stem cells. Bone Res. 2014;2:14017.

87. Verma S, Domb AJ, Kumar N. Nanomaterials for regenerative medicine. Nanomedicine (Lond). 2011;6:157-181.

88. Madhumathi K, Sampath Kumar TS. Regenerative potential and anti-bacterial activity of tetracycline loaded apatitic nanocarriers for the treatment of periodontitis. Biomed Mater. 2014;9:35002.

89. Choi B, Cui Z-K, Kim S, Fan J, Wu BM, Lee M. Glutaminechitosan modified calcium phosphate nanoparticles for efficient siRNA delivery and osteogenic differentiation. J Mater Chem B. 2015;3:6448-6455.

90. Hench LL, Splinter RJ, Allen WC, Greenlee TK. Bonding mechanisms at the interface of ceramic prosthetic materials. J Biomed Mater Res. 1971;5:117-141.

91. Jones JR. Review of bioactive glass: from Hench to hybrids. Acta Biomater. 2013;9:4457-4486.

92. Hench LL, Paschall HA. Direct chemical bond of bioactive glass-ceramic materials to bone and muscle. J Biomed Mater Res. 1973;7:25-42.

93. Hong Z, Luz GM, Hampel PJ, Jin M, Liu A, Chen X, Mano JF. Mono-dispersed bioactive glass nanospheres: preparation and effects on biomechanics of mammalian cells. J Biomed Mater Res A. 2010;95:747-754.

94. Erol-Taygun M, Zheng K, Boccaccini AR. Nanoscale bioactive glasses in medical applications. Int J Appl Glas Sci. 2013;4: 136-148.

95. Misra SK, Ansari T, Mohn D, Valappil SP, Brunner TJ, Stark WJ, Roy I, Knowles JC, Sibbons PD, Jones EV, Boccaccini AR, Salih V. Effect of nanoparticulate bioactive glass particles on bioactivity and cytocompatibility of poly(3-hydroxybutyrate) composites. J R Soc Interface. 2010;7:453-465.

96. Ji L, Wang W, Jin D, Zhou S, Song X. In vitro bioactivity and mechanical properties of bioactive glass nanoparticles/polycaprolactone composites. Mater Sci Eng C Mater Biol Appl. 2015;46:1-9.

97. Leite ÁJ, Caridade SG, Mano JF. Synthesis and characterization of bioactive biodegradable chitosan composite spheres with shape memory capability. J Non Cryst Solids. doi:https://doi.org/ 10.1016/j.jnoncrysol.2015.04.011.

98. Zhang Y, Bai Y, Yan B. Functionalized carbon nanotubes for potential medicinal applications. Drug Discov Today. 2010;15: $428-435$. 
99. Balasubramanian K, Burghard M. Chemically functionalized carbon nanotubes. Small. 2005;1:180-192.

100. Liu Y, Zhao Y, Sun B, Chen C. Understanding the toxicity of carbon nanotubes. Acc Chem Res. 2013;46:702-713.

101. Massey M, Wu M, Conroy EM, Algar WR. Mind your P's and Q's: the coming of age of semiconducting polymer dots and semiconductor quantum dots in biological applications. Curr Opin Biotechnol. 2014;34C:30-40.

102. Perán M, García MA, López-Ruiz E, Bustamante M, Jiménez G, Madeddu R, Marchal JA. Functionalized nanostructures with application in regenerative medicine. Int J Mol Sci. 2012; 13:3847-3886.

103. Li P, Sun P, Yang W, Zhang X. Real-time mapping of rat stomach lymph nodes by quantum dots. Scand J Gastroenterol. 2012;47:454-460.

104. Deerinck TJ. The application of fluorescent quantum dots to confocal, multiphoton, and electron microscopic imaging. Toxicol Pathol. 2008;36:112-116.

105. Petryayeva E, Algar WR, Medintz IL. Quantum dots in bioanalysis: a review of applications across various platforms for fluorescence spectroscopy and imaging. Appl Spectrosc. 2013; 67:215-252.

106. Derfus AM, Chan WCW, Bhatia SN. Probing the cytotoxicity of semiconductor quantum dots. Nano Lett. 2004;4:11-18.

107. Lovrić J, Cho SJ, Winnik FM, Maysinger D. Unmodified cadmium telluride quantum dots induce reactive oxygen species formation leading to multiple organelle damage and cell death. Chem Biol. 2005;12:1227-1234.

108. Tsoi KM, Dai Q, Alman BA, Chan WCW. Are quantum dots toxic? Exploring the discrepancy between cell culture and animal studies. Acc Chem Res. 2013;46:662-671.

109. Chang E, Thekkek N, Yu WW, Colvin VL, Drezek R. Evaluation of quantum dot cytotoxicity based on intracellular uptake. Small. 2006;2:1412-1417.

110. Chinnathambi S, Chen S, Ganesan S, Hanagata N. Silicon quantum dots for biological applications. Adv Healthcare Mater. 2014;3:10-29.

111. Huang X, Zhang F, Zhu L, Choi KY, Guo N, Guo J, Tackett K, Anilkumar P, Liu G, Quan Q, Choi HS, Niu G, Sun YP, Lee S, Chen X. Effect of injection routes on the biodistribution, clearance, and tumor uptake of carbon dots. ACS Nano. 2013;7:5684-5693.

112. Hutmacher DW. Scaffolds in tissue engineering bone and cartilage. Biomaterials. 2000;21:2529-2543.

113. Alves Cardoso D, Jansen JA, G, Leeuwenburgh SC. Synthesis and application of nanostructured calcium phosphate ceramics for bone regeneration. J Biomed Mater Res B Appl Biomater. 2012;100B:2316-2326.

114. Gupte MJ, Ma PX. Nanofibrous scaffolds for dental and craniofacial applications. J Dent Res. 2012;91:227-234.

115. Deplaine H, Lebourg M, Ripalda P, Vidaurre A, Sanz-Ramos P, Mora G, Prósper F, Ochoa I, Doblaré M, Gómez Ribelles JL, Izal-Azcárate I, Gallego Ferrer G. Biomimetic hydroxyapatite coating on pore walls improves osteointegration of poly(Llactic acid) scaffolds. J Biomed Mater Res B Appl Biomater. 2013;101:173-186.

116. Zhou H, Touny AH, Bhaduri SB. Fabrication of novel PLA/ CDHA bionanocomposite fibers for tissue engineering applications via electrospinning. J Mater Sci Mater Med. 2011;22: $1183-1193$.

117. Peter M, Ganesh N, Selvamurugan N, Nair SV, Furuike T, Tamura H, Jayakumar R.. Preparation and characterization of chitosan-gelatin/nanohydroxyapatite composite scaffolds for tissue engineering applications. Carbohydr Polym. 2010;80: 687-694.

118. Ganesh N, Ashokan A, Rajeshkannan R, Chennazhi K, Koyakutty M, Nair SV. Magnetic resonance functional nano-hydroxyapatite incorporated poly(caprolactone) composite scaffolds for in situ monitoring of bone tissue regeneration by MRI. Tissue Eng A. 2014;20:2783-2794

119. Yan L-P, Salgado AJ, Oliveira JM, Oliveira AL, Reis RL. De novo bone formation on macro/microporous silk and silk/nanosized calcium phosphate scaffolds. J Bioact Compat Polym. 2013;28:439-452.
120. Hafezi F, Hosseinnejad F, Fooladi AAI, Mafi SM, Amiri A, Nourani MR. Transplantation of nano-bioglass/gelatin scaffold in a non-autogenous setting for bone regeneration in a rabbit ulna. J Mater Sci Mater Med. 2012;23:2783-2792.

121. Roohani-Esfahani SI, Nouri-Khorasani S, Lu ZF, Appleyard RC, Zreiqat $\mathrm{H}$. Effects of bioactive glass nanoparticles on the mechanical and biological behavior of composite coated scaffolds. Acta Biomater. 2011;7:1307-1318.

122. Pourhaghgouy M, Zamanian A, Shahrezaee M, Masouleh MP. Physicochemical properties and bioactivity of freeze-cast chitosan nanocomposite scaffolds reinforced with bioactive glass. Mater Sci Eng C. 2016;58:180-186.

123. Olmos Buitrago J, Perez RA, El-Fiqi A, Singh RK, Kim J-H, Kim $\mathrm{H}-\mathrm{W}$. Core-shell fibrous stem cell carriers incorporating osteogenic nanoparticulate cues for bone tissue engineering. Acta Biomater. 2015;28:183-192.

124. Cheng Q, Rutledge K, Jabbarzadeh E. Carbon nanotube-poly(lactide-co-glycolide) composite scaffolds for bone tissue engineering applications. Ann Biomed Eng. 2013;41:904-916.

125. Chen L, Hu J, Shen X, Tong H. Synthesis and characterization of chitosan-multiwalled carbon nanotubes/hydroxyapatite nanocomposites for bone tissue engineering. J Mater Sci Mater Med. 2013;24:1843-1851.

126. Li X, Gao H, Uo M, Sato Y, Akasaka T, Feng Q, Cui F, Liu $\mathrm{X}$, Watari F. Effect of carbon nanotubes on cellular functions in vitro. J Biomed Mater Res A. 2009;91A:132-139.

127. Gupta A, Main BJ, Taylor BL, Gupta M, Whitworth CA, Cady C, Freeman JW, El-Amin SF. In vitro evaluation of threedimensional single-walled carbon nanotube composites for bone tissue engineering. J Biomed Mater Res A. 2014;102: $4118-4126$.

128. Castro E, Mano JF. Magnetic force-based tissue engineering and regenerative medicine. J Biomed Nanotechnol. 2013;9: $1129-1136$.

129. Meng J, Xiao B, Zhang Y, Liu J, Xue H, Lei J, Kong H, Huang Y, Jin Z, Gu N, Xu H. Super-paramagnetic responsive nanofibrous scaffolds under static magnetic field enhance osteogenesis for bone repair in vivo. Sci Rep. 2013;3:2655.

130. Zeng XB, Hu H, Xie LQ, Lan F, Jiang W, Wu Y, Gu ZW. Magnetic responsive hydroxyapatite composite scaffolds construction for bone defect reparation. Int J Nanomed. 2012;7: $3365-3378$

131. Zhang D, Liu D, Zhang J, Fong C, Yang M. Gold nanoparticles stimulate differentiation and mineralization of primary osteoblasts through the ERK/MAPK signaling pathway. Mater Sci Eng C. 2014;42:(0):70-77.

132. Ko W-K, Heo DN, Moon H-J, Lee SJ, Bae MS, Lee JB, Sun IC, Jeon HB, Park HK, Kwon IK. The effect of gold nanoparticle size on osteogenic differentiation of adipose-derived stem cells. J Colloid Interface Sci. 2015;438:68-76.

133. Heo DN, Ko W-K, Bae MS, Lee JB, Lee DW, Byun W, Lee $\mathrm{CH}$, Kim EC, Jung BY, Kwon IK. Enhanced bone regeneration with a gold nanoparticle-hydrogel complex. J Mater Chem B. 2014;2:1584-1593.

134. Tautzenberger A, Kovtun I. Nanoparticles and their potential for application in bone. Int $J$ Nanomed. 2012;4545:doi: 10.2147/IJN.S34127.

135. Kamath MS, Ahmed SS, Dhanasekaran M, Santosh SW. Polycaprolactone scaffold engineered for sustained release of resveratrol: therapeutic enhancement in bone tissue engineering. Int J Nanomed. 2014;9:183-195.

136. Dyondi D, Webster TJ, Banerjee R. A nanoparticulate injectable hydrogel as a tissue engineering scaffold for multiple growth factor delivery for bone regeneration. Int J Nanomed. 2013;8:47-59.

137. Santo VE, Gomes ME, Mano JF, Reis RL. Chitosan-chondroitin sulphate nanoparticles for controlled delivery of platelet lysates in bone regenerative medicine. J Tissue Eng Regen Med. 2012;6:s47-s59.

138. Park K-H, Kim H, Moon S, Na K. Bone morphogenic protein2 (BMP-2) loaded nanoparticles mixed with human mesenchymal stem cell in fibrin hydrogel for bone tissue engineering. J Biosci Bioeng. 2009;108:530-537. 
139. Yilgor $P$, Hasirci N, Hasirci V. Sequential BMP-2/BMP-7 delivery from polyester nanocapsules. J Biomed Mater Res A. 2010;93A:528-536.

140. Kim S, Jeon O, Lee J, Bae M, Chun HJ, Moon SH, Kwon I. Enhancement of ectopic bone formation by bone morphogenetic protein-2 delivery using heparin-conjugated PLGA nanoparticles with transplantation of bone marrow-derived mesenchymal stem cells. J Biomed Sci. 2008;15:771-777.

141. Mercado AE, Ma J, He X, Jabbari E. Release characteristics and osteogenic activity of recombinant human bone morphogenetic protein- 2 grafted to novel self-assembled poly(lactide-coglycolide fumarate) nanoparticles. J Control Release. 2009; 140:148-156.

142. Oliveira JM, Sousa RA, Kotobuki N, Tadokoro M, Hirose M, Mano JF, Reis RL, Ohgushi H. The osteogenic differentiation of rat bone marrow stromal cells cultured with dexamethasoneloaded carboxymethylchitosan/poly(amidoamine) dendrimer nanoparticles. Biomaterials. 2009;30:804-813.

143. Oliveira JM, Kotobuki N, Tadokoro M, Hirose M, Mano JF, Reis RL, Ohgushi H. Ex vivo culturing of stromal cells with dexamethasone-loaded carboxymethylchitosan/poly(amidoamine) dendrimer nanoparticles promotes ectopic bone formation. Bone. 2010;46:1424-1435. Available at: http://linkinghub.elsevier.com/ retrieve/pii/S8756328210004291?showall $=$ true.

144. Monteiro N, Martins A, Ribeiro D, Faria S, Fonseca NA, Moreira JN, Reis RL, Neves NM. On the use of dexamethasone-loaded liposomes to induce the osteogenic differentiation of human mesenchymal stem cells. J Tissue Eng Regen Med. 2013:n/a-n/a. doi:10.1002/term.1817.

145. Marquez L, de Abreu FAM, Ferreira CL, Alves GD, Miziara MN, Alves JB. Enhanced bone healing of rat tooth sockets after administration of epidermal growth factor (EGF) carried by liposome. Injury. 2013;44:558-564. Available at: http://linkinghub.elsevier. com/retrieve/pii/S0020138312004639?showall = true.

146. Wang G, Babadagli ME, Uludag H. Bisphosphonate-derivatized liposomes to control drug release from collagen/hydroxyapatite scaffolds. Mol Pharm. 2011;8:1025-1034.

147. Kim TH, Kim M, Eltohamy M, Yun YR, Jang JH, Kim HW. Efficacy of mesoporous silica nanoparticles in delivering BMP-2 plasmid DNA for in vitro osteogenic stimulation of mesenchymal stem cells. J Biomed Mater Res A. 2013;101: 1651-1660. Available at: http://europepmc.org/abstract/MED/ 23184619.

148. Hu Y, Cai K, Luo Z, Jandt KD. Layer-by-layer assembly of $\beta$ estradiol loaded mesoporous silica nanoparticles on titanium substrates and its implication for bone homeostasis. Adv Mater. 2010;22:4146-4150.

149. Xie G, Sun J, Zhong G, Liu C, Wei J. Hydroxyapatite nanoparticles as a controlled-release carrier of BMP-2: absorption and release kinetics in vitro. J Mater Sci Mater Med. 2010;21: $1875-1880$.

150. Krebs MD, Salter E, Chen E, Sutter KA, Alsberg E. Calcium phosphate-DNA nanoparticle gene delivery from alginate hydrogels induces in vivo osteogenesis. J Biomed Mater Res A. 2010;92:A1131-1138.

151. Jensen T, Baas J, Dolathshahi-Pirouz A, Jacobsen T, Singh G, Nygaard JV, Foss M, Bechtold J, Bünger C, Besenbacher F, Søballe K. Osteopontin functionalization of hydroxyapatite nanoparticles in a PDLLA matrix promotes bone formation. J Biomed Mater Res A. 2011;99A:94-101.

152. Rodan GA. Bone homeostasis. Proc Natl Acad Sci. 1998;95: 13361-13362.

153. van Gaalen S, Kruyt M, Meijer G, Mistry A, Mikos A, van den Beucken J, Jansen J, de Groot K, Cancedda R, Olivo C, Yaszemski M, Dhert W. Chapter 19 - Tissue engineering of bone. In: van Blitterswijk C, Thomsen P, Lindahl A, Hubbell J, Williams DF, Cancedda R, de Bruijn JD, Sohier J, editors. Tissue Engineering. Burlington: Academic Press; 2008:559610.

154. Haidar Z, Hamdy R, Tabrizian M. Delivery of recombinant bone morphogenetic proteins for bone regeneration and repair. Part B: Delivery systems for BMPs in orthopaedic and craniofacial tissue engineering. Biotechnol Lett. 2009;31:1825-1835.
155. Cao L, Werkmeister JA, Wang J, Glattauer V, McLean KM, Liu C. Bone regeneration using photocrosslinked hydrogel incorporating rhBMP-2 loaded 2-N, 6-O-sulfated chitosan nanoparticles. Biomaterials. 2014;35:2730-2742.

156. den Uyl D, Bultink IEM, Lems WF. Glucocorticoid-induced osteoporosis. Clin Exp Rheumatol. 2011;29:S93-S98. Available at: http://www.ncbi.nlm.nih.gov/pubmed/22105813.

157. Hasani-Sadrabadi MM, Pour Hajrezaei S, Hojjati Emami S, Bahlakeh G, Daneshmandi L, Dashtimoghadam E, Seyedjafari E, Jacob KI, Tayebi L. Enhanced osteogenic differentiation of stem cells via microfluidics synthesized nanoparticles. Nanomedicine. 2015;11:1809-1819.

158. Zhou X, Feng W, Qiu K, Chen L, Wang W, Nie W, Mo X, He C. BMP-2 derived peptide and dexamethasone incorporated mesoporous silica nanoparticles for enhanced osteogenic differentiation of bone mesenchymal stem cells. ACS Appl Mater Interfaces. 2015;7:15777-15789.

159. Zhou T-H, Su M, Shang B-C, Ma T, Xu G-L, Li H-L, Chen Q-H, Sun $\mathrm{W}$, Xu Y-Q. Nano-hydroxyapatite/ $\beta$-tricalcium phosphate ceramics scaffolds loaded with cationic liposomal ceftazidime: preparation, release characteristics in vitro and inhibition to Staphylococcus aureus biofilms. Drug Dev Ind Pharm. 2012;38: 1298-1304.

160. Jiang T, Yu X, Carbone EJ, Nelson C, Kan HM, Lo KW-H. Poly aspartic acid peptide-linked PLGA based nanoscale particles: potential for bone-targeting drug delivery applications. Int $J$ Pharm. 2014;475:547-557.

161. Yin H, Kanasty RL, Eltoukhy AA, Vegas AJ, Dorkin JR, Anderson DG. Non-viral vectors for gene-based therapy. Nat Rev Genet. 2014; 15:541-555.

162. Lu C-H, Chang Y-H, Lin S-Y, Li K-C, Hu Y-C. Recent progresses in gene delivery-based bone tissue engineering. Biotechnol Adv. 2013;31:1695-1706.

163. Qureshi AT, Monroe WT, Dasa V, Gimble JM, Hayes DJ. miR-148b-nanoparticle conjugates for light mediated osteogenesis of human adipose stromal/stem cells. Biomaterials. 2013; 34:7799-7810.

164. Qureshi AT, Doyle A, Chen C, Coulon D, Dasa V, Del Piero F, Levi B, Monroe WT, Gimble JM, Hayes DJ. Photoactivated miR-148b-nanoparticle conjugates improve closure of critical size mouse calvarial defects. Acta Biomater. 2015;12:166-173.

165. Mizuno H, Tobita M, Uysal AC. Concise review: adiposederived stem cells as a novel tool for future regenerative medicine. Stem Cells. 2012;30:804-810.

166. Kiessling F, Mertens ME, Grimm J, Lammers T. Nanoparticles for imaging: top or flop? Radiology. 2014;273:10-28.

167. Rümenapp C, Gleich B, Haase A. Magnetic nanoparticles in magnetic resonance imaging and diagnostics. Pharm Res. 2012;29:1165-1179.

168. Clark DP, Badea CT. Micro-CT of rodents: State-of-the-art and future perspectives. Physica Medica. 2014;

169. Yuan Z, Jiang H. Photoacoustic tomography for imaging nanoparticles. In: Grobmyer SR, Moudgil BM, editors. Cancer Nanotechnology SE - 21, Vol 624. Methods in Molecular Biology. Humana Press; 2010:309-324.

170. Pittenger MF. Multilineage potential of adult human mesenchymal stem cells. Science. 1999;284:143-147.

171. Chang Y-K, Liu Y-P, Ho JH, Hsu S-C, Lee OK. Amine-surface-modified superparamagnetic iron oxide nanoparticles interfere with differentiation of human mesenchymal stem cells. J Orthop Res. 2012;30:1499-1506.

172. Fan J, Tan Y, Jie L, Wu X, Yu R, Zhang M. Biological activity and magnetic resonance imaging of superparamagnetic iron oxide nanoparticles-labeled adipose-derived stem cells. Stem Cell Res Ther. 2013;4:44.

173. Suh JS, Lee JY, Choi YS, Yu F, Yang V, Lee SJ, Chung CP, Park YJ. Efficient labeling of mesenchymal stem cells using cell permeable magnetic nanoparticles. Biochem Biophys Res Commun. 2009;379:669-675.

174. van Buul GM, Kotek G, Wielopolski PA, Farrell E, Bos PK, Weinans H, Grohnert AU, Jahr H, Verhaar JAN, Krestin GP, van Osch GJVM, Bernsen MR. Clinically translatable cell tracking and quantification by MRI in cartilage repair using 
superparamagnetic iron oxides. PLoS One. 2011;6:e17001. Available at. https://doi.org/10.1371/journal.pone.0017001.

175. Ricles LM, Nam SY, Sokolov K, Emelianov SY, Suggs LJ. Function of mesenchymal stem cells following loading of gold nanotracers. Int J Nanomed. 2011;6:407-416.

176. Shen Y, Shao Y, He H, Tan Y, Tian X, Xie F, Li L. Gadolinium3+-doped mesoporous silica nanoparticles as a potential magnetic resonance tracer for monitoring the migration of stem cells in vivo. Int J Nanomed. 2013;8:119-127.

177. Dupont KM, Sharma K, Stevens HY, Boerckel JD, García AJ, Guldberg RE. Human stem cell delivery for treatment of large segmental bone defects. Proc Natl Acad Sci. 2010; doi: 10.1073/pnas.0905444107.

178. Chen Y-C, Hsiao J-K, Liu H-M, Lai I-Y, Yao M, Hsu S-C, Ko B-S, Chen Y-C, Yang C-S, Huang D-M. The inhibitory effect of superparamagnetic iron oxide nanoparticle (Ferucarbotran) on osteogenic differentiation and its signaling mechanism in human mesenchymal stem cells. Toxicol Appl Pharmacol. 2010;245:272-279.

179. Jasmin Torres ALM, Nunes HM, Passipieri JA, Jelicks LA, Gasparetto EL, Spray DC, Campos de Carvalho AC, MendezOtero R. Optimized labeling of bone marrow mesenchymal cells with superparamagnetic iron oxide nanoparticles and in vivo visualization by magnetic resonance imaging. J Nanobiotechnology. 2011;9:4.
180. Tsai S-W, Liaw J-W, Kao Y-C, Huang M-Y, Lee C-Y, Rau L$\mathrm{R}$, Huang C-Y, Wei K-C, Ye T-C. Internalized gold nanoparticles do not affect the osteogenesis and apoptosis of MG63 osteoblast-like cells: a quantitative, in vitro study. PLoS One. 2013;8:e76545. Available at: https://doi.org/10.1371/journal. pone.0076545.

181. Shin SR, Shin C, Memic A, Shadmehr S, Miscuglio M, Jung HY, Jung SM, Bae H, Khademhosseini A, Tang X, Dokmec MR. Aligned carbon nanotube-based flexible gel substrates for engineering biohybrid tissue actuators. Adv Funct Mater. 2015; 25:4486-4495.

182. Nair AK, Gautieri A, Chang S-W, Buehler MJ. Molecular mechanics of mineralized collagen fibrils in bone. Nat Commun. 2013;4:1724.

183. McMahon RE, Wang L, Skoracki R, Mathur AB. Development of nanomaterials for bone repair and regeneration. $J$ Biomed Mater Res B Appl Biomater. 2013;101:387-397.

184. Wang Y, Zhao Q, Han N, Bai L, Li J, Liu J, Che E, Hu L, Zhang Q, Jiang T, Wang S. Mesoporous silica nanoparticles in drug delivery and biomedical applications. Nanomed Nanotechnol Biol Med. 2015;11:313-327.

Manuscript received June 20, 2016, and revision received Mar. 14, 2017. 